\title{
Reputation, Price, and Death: An Empirical Analysis of Art Price Formation
}

\author{
HEINRICH W. URSPRUNG \\ CHRISTIAN WIERMANN
}

CESIFO WORKING PAPER No. 2237

CATEGORY 9: INDUSTRIAL ORGANISATION

MARCH 2008

\footnotetext{
An electronic version of the paper may be downloaded

- from the SSRN website:

www.SSRN.com

- from the RePEc website:

- from the CESifo website:

www.RePEc.org

www.CESifo-group.org/wp
} 


\title{
Reputation, Price, and Death: An Empirical Analysis of Art Price Formation
}

\begin{abstract}
We analyze how an artist's death influences the market prices of her works of art. Death has two opposing effects on art prices. By irrevocably restricting the artist's oeuvre, prices, ceteris paribus, increase when the artist dies. On the other hand, an untimely death may well frustrate the collectors' hopes of owning artwork that will, as the artist's career progresses, become generally known and appreciated. By frustrating expected future name recognition, death impacts negatively on art prices. In conjunction, these two channels of influence give rise to a hump-shaped relationship between age at death and death-induced price changes. Using transactions from fine art auctions, we show that the empirically identified death effects indeed conform to our theoretical predictions. We derive our results from hedonic art price regressions, making use of a data set which exceeds the sample size of traditional studies in cultural economics by an order of magnitude.
\end{abstract}

JEL Code: Z11, J24, G12.

Keywords: art price formation, death effect, durable goods monopoly.

Heinrich W. Ursprung

Department of Economics

University of Konstanz

Box D-138

78457 Konstanz

Germany

Heinrich.Ursprung@uni-konstanz.de
Christian Wiermann

Department of Economics

University of Konstanz

Box D-138

78457 Konstanz

Germany

Christian.Wiermann@uni-konstanz.de

29 January 2008

We thank Günther Schulze for helpful comments. 


\section{REPUTATION, PRICE, AND DEATH: \\ AN EMPIRICAL ANALYSIS OF ART PRICE FORMATION}

\section{Introduction}

Art prices are often claimed to substantially increase when the artist dies. These claims appear to be largely based on anecdotal evidence. They are promulgated by hearsay and sometimes cleverly insinuated by art dealers who attempt to convince naïve customers that it is justified to mark up the artwork of recently deceased artists. This study provides a theory-guided empirical analysis of the socalled "death effect" on art prices. The analysis employs hedonic price regressions and makes use of a dataset which exceeds the sample size of traditional studies in cultural economics by an order of magnitude, thereby shedding a new light on previous investigations of art price formation.

Even though the literature on art auctions, art price indices, and rates of return in the visual arts market is by now quite voluminous (see, repectively, Ashenfelter and Graddy, 2006, Ginsburgh, Mei and Moses, 2006, and Frey and Eichenberger, 1995), the death effect has not received much attention so far. To be sure, there are a few empirical studies which allow for a death effect, but these studies do so in a rather cursory and off-handed manner by merely including in their regressions a dummy variable that distinguishes between works of art created by living and late artists (see, for example, Agnello, 2002, and Worthington and Higgs, 2006).

The first investigation that has squarely addressed death-induced art price changes is Ekelund, Ressler and Watson (2000). These authors go some way in providing a theoretical underpinning of the death effect by pointing out that artists produce durable goods under market conditions of monopolistic competition. Thus, given rational actors in the art market, the Coase Conjecture applies (Coase, 1972): even though artists have, in principle, some discretion in setting prices, they cannot exert market power because they are unable to credibly commit to not lowering their prices in the future by spoiling the market with an inflationary increase in production. During an artist's lifetime, prices will therefore settle well below the monopoly price. Death, of course, is the ultimate device to commit to discontinuing production. Art prices thus increase when the artist dies because her oeuvre all of a sudden becomes scarcer than originally anticipated. After having laid this theoretical foundation, Ekelund, Ressler and Watson proceed to empirically identify the death effect with the help of a hedonic price regression. Their data consists of a panel of auction records relating to the work of 21 Latin American artists who died near or during the observation period (1977-1996). The prices are shown to peak in the years immediately following an artist's death, thus lending support to the existence of a death effect.

From a theoretical point of view, the main concern with this pioneering analysis relates to the artists' age at death. Since the probability of dying increases with age, the information of an old artist's death is not very surprising and should therefore already be largely reflected in the price, implying a small 
death effect. The death of an old artist, moreover, causes a relatively small reduction in the anticipated size of her oeuvre which, again, translates into a relatively small price increase when her death is made public. Assuming rational expectations, one would therefore expect the death effect to decrease with the artist's age at death. A formal rendering of this argument is to be found in Itaya and Ursprung (2008) who investigate the death effect in an infinite-horizon dynamic general equilibrium setting. It therefore stands to reason that the death effect depends on the age at death. Neglecting this relationship in empirical investigations may, of course, give rise to a seriously misspecified econometric model.

A recent study by Maddison and Jul-Perdersen (2007) acknowledges that the prices of an artist's works should depend on the expected total supply which, in turn, depends on the artist's conditional life expectancy at the time of sale. Using a data set comprising auction prices of oil paintings by Danish artists who died during the period 1983-2003, Maddison and Jul-Perdersen show that the variable "conditional life expectancy" (which, by definition, assumes the value of zero for artists who are not alive anymore at the time of sale) has a significant negative effect on art prices in their hedonic fixed-effects panel regression, while the dummy variable indicating whether the artist was dead or alive at the time of sale does not appear to have an independent significant influence. These results are compatible with a positive death effect that decreases with the age at death.

Our empirical strategy is to identify the relationship between the death effect and the artists' age at death more directly. We also employ hedonic fixed-effect panel regressions which however include a polynomial of the age at death to explain the prices of those pieces of art whose creators have died shortly before the respective transaction has taken place. Our dataset comprises a selection of 436,308 transactions extracted from Hislop's Art Sale Index (1980-2005). It is thus much larger than the datasets used so far in empirical studies of art price formation. ${ }^{1}$ In any event, it is sufficiently large to estimate the influence of low-impact determinants even for relatively small price segments of the art market with the help of quantile regressions.

Our empirical analysis is guided by theoretical considerations. Since reputation plays a major role in the arts market (cf. Beckert and Rössel, 2004), we analyze a durable goods monopoly model which encompasses reputation-induced demand. Our main result shows that the relationship between the death effect and the artists' age at death is inversely u-shaped: the death of young artists actually decreases the price of their works of art, whereas the death effect is positive for older artists and disappears for artist's who die at a very old age. This pattern perfectly matches our predictions. The negative price effect of untimely deaths, which has not been considered in the literature so far, is a straight forward consequence of reputation-induced demand for works of fine art. The basic mechanism works as follows. At the beginning of their careers, artists have no far-reaching reputation to speak of. Nevertheless, collectors who happen to be familiar with the work of promising young

\footnotetext{
${ }^{1}$ To provide a reference point, we report here the number of observations of the studies cited above: 630 (Ekelund et al., 2000), 4857 (Maddison and Jul-Pederssen, 2007), 25,217 (Agnello, 2002), and 30,227 (Worthington and Higgs, 2006).
} 
artists might well pay a considerable price for their works of art since they expect these artists to eventually obtain a reputation that justifies the price they pay for the fledgling's work. If such an artist dies an untimely death, her lifetime oeuvre might not be sufficiently substantial to generate the expected reputation, and the price drops. There are thus two mechanisms determining the death effect: the standard positive effect deriving from unexpected scarcity of supply and a negative effect deriving from frustrated demand-side expectations of artistic reputation. Both effects disappear for artist's who die at a ripe old age. In conjunction, the scarcity and the reputation effect give rise to the identified inversely u-shaped relationship between death-related price changes and age at death.

In deriving this relationship, we follow a minimalist modelling strategy, i.e. we only portray those stylized facts of the art market that are absolutely necessary to arrive at the empirically identified price pattern. In particular, we do not replicate the approach employed by Itaya and Ursprung (2008) who derive optimal consumption and production paths for the collectors and artists, albeit without considering reputation-induced utility on the part of the collectors. We rather proceed directly from a postulated market demand function and assume that the artists' flow production is constant over career time and homogenous. This portrait of the production process is admittedly quite stark: the optimal production path derived in the study by Itaya and Ursprung (2008) suggests, for example, that production declines over an artist's career time, and various empirical studies indicate that some artists' early work is most highly appreciated, whereas others produce their most successful work at a more mature age (see, for example, Galenson and Weinberg, 2000 and 2001, and Edwards, 2004). All of these idiosyncrasies of artistic production do however not affect the qualitative conclusions of our main argument. To minimize nomenclature, we therefore chose to associate an artist's stock of finished works of art with his or her career age by assuming a constant flow production of homogenous works of art. We also assume an efficient arts market which presupposes well functioning institutions. Again, in an attempt to arrive at a minimalist model, we chose not to portray the respective institutional details. We simply assume that the established modern gallery system, as it developed after WWII, is able to match the collectors' demand with the supply in a frictionless manner.

The paper unfolds as follows. Our minimalist model is developed in Section 2. In Section 3 we present the empirical methodology and our dataset. The estimates with respect to the variables that have traditionally been used in hedonic art price regressions are discussed in Section 4. In Section 5 we turn to our estimates of the death effect. We first show OLS estimates based on our full sample of auction records. In a second step, we then reduce the sample size in order to be able to estimate quantile regressions which serve, on the one hand, as a robustness test of our OLS estimates. On the other hand, these quantile regressions also shed some new light on art price formation in the middle and high-end segment of the art market. Section 6 concludes. 


\section{A minimalist model}

Consider the oeuvre of a deceased artist. The price of her artwork varies positively with the quality as perceived by the contemporary collectors and, according to the law of demand, with scarcity. We capture these determinants with a standard downward-sloping demand function $\mathrm{D}(\mathrm{X})$, where $\mathrm{X}$ denotes the size of the artist's lifetime oeuvre. The art price also depends on the artist's reputation. To gain a reputation in the global art scene, an artist's work needs to be well known to a large audience which implies that reputation, ceteris paribus, increases with the size $\mathrm{X}$ of the oeuvre. ${ }^{2}$ Let the increasing function $\mathrm{R}(\mathrm{X})$ describe the impact of reputation on the art price and let the "estate" price be defined as $\mathrm{P}_{\mathrm{e}}(\mathrm{X})=\mathrm{D}(\mathrm{X})+\mathrm{R}(\mathrm{X})$. It can safely be assumed that the reputation effect $\mathrm{R}(\mathrm{X})$ dominates the scarcity effect $D(X)$ for sufficiently small oeuvres, implying that $P_{e}(X)$ is initially increasing in $X$. For large lifetime $\mathrm{D}(\mathrm{X})$ oeuvres $\mathrm{X}$, the scarcity effect may take over to give rise to a single peaked demand function.

The following specification serves as an illustration. Let $\mathrm{D}(\mathrm{X})=\mathrm{a}-\mathrm{bX}$, and $\mathrm{R}(\mathrm{X})=\mathrm{rX}$ for $\mathrm{X}<\hat{\mathrm{X}}$ and $\mathrm{R}(\mathrm{X})=\mathrm{r} \hat{\mathrm{X}}$ for $\mathrm{X} \geq \hat{\mathrm{X}}$, where $\mathrm{r}>\mathrm{b}$. We thus assume that reputation increases with $\mathrm{X}$ as long as the oeuvre $\mathrm{X}$ falls short of the critical size $\hat{\mathrm{X}}$. The parameters $\mathrm{a}, \mathrm{b}$ and $\mathrm{r}$ capture the quality of the artist's work, the price-sensitivity of scarcity, and the price-sensitivity of reputation. The resulting estate price equation has the following appearance:

$$
P_{e}(X)=\left\{\begin{array}{l}
a-(b-r) X, \text { for } X<\hat{X} \\
a+r \hat{X}-b X, \text { for } X \geq \hat{X}
\end{array}\right.
$$

In order to determine the price of the works of art of a living artist, we assume that the collectors are perfectly rational and risk neutral; to be more precise, they are at each point of time willing to pay a price that is consistent with the price that is expected to prevail in the long run when (as the art lover John Maynard Keynes pointed out in a different context) the artist will be dead and the estate price as given in equation (1) applies. In period (year) t, a living artist's work thus commands the price

$$
\begin{aligned}
& P(t)=m_{t} P_{e}\left(\sum_{k=\underline{t}}^{t} x_{k}\right)+\left(1-m_{t}\right) m_{t+1} P_{e}\left(\sum_{k=\underline{t}}^{t+1} x_{k}\right)+\left(1-m_{t}\right)\left(1-m_{t+1}\right) m_{t+2} P_{e}\left(\sum_{k=\underline{t}}^{t+2} x_{k}\right)+\ldots \\
& =\sum_{k=t}^{\bar{t}}\left[m_{k}\left\langle\prod_{s=t}^{k-1}\left(1-m_{s}\right)\right\rangle P_{e}\left(\sum_{j=\underline{t}}^{k} x_{j}\right)\right],
\end{aligned}
$$

where $m_{k}$ denotes the mortality rate, i.e. the probability of dying at the end of year $k$, and $x_{k}$ the artistic output in year k. In the simplest possible model of artistic production, output is constant over career time, i.e. $x_{k}=1$ for $t \leq k \leq \bar{t}$ and $x_{k}=0$ otherwise, where $t$ marks the beginning of the artist's career, $\bar{t}$

\footnotetext{
${ }^{2}$ The assumption that reputation varies positively with the size of the oeuvre, or, alternatively, with career age, is supported by the empirical evidence provided by Beckert and Rössel (2004).
} 
the retirement age, and output is normalized to unity. Assuming constant production has the advantage that the artist's oeuvre $\sum_{\mathrm{k}=\underline{\mathrm{t}}}^{\mathrm{t}} \mathrm{x}_{\mathrm{k}}$ can be expressed by her (career) age.

Using a numerical specification of the estate price equation (1) and mortality rates from a real world life table, the period art prices $\mathrm{P}(\mathrm{t})$ can easily be computed from equation (2). ${ }^{3}$ We assume in our example that the artists' careers begin at age $\underline{t}=20$, that they retire at age $\overline{\mathrm{t}}=89$ (the last age for which reliable mortality rates are available), and that reputation reaches the maximum level after 50 years of productive life (i.e. $\hat{X}=50$, or, alternatively, $\hat{t}=70$ ). Furthermore, we assume $a=10, b=0.1$ and $\mathrm{r}=0.2$. The resulting period prices $\mathrm{P}(\mathrm{t})$ are depiced in the first panel of Figure 1 together with the estate prices $P_{e}(t)$, where $P_{e}(t)$ is the price that prevails after the artist's death at age t. The second panel depicts the death effect $\Delta(\mathrm{t})$, expressed as the percentage change in the art price if the artist dies at age $\mathrm{t}: \Delta(\mathrm{t})=\left[\mathrm{P}_{\mathrm{e}}(\mathrm{t})-\mathrm{P}(\mathrm{t})\right] / \mathrm{P}(\mathrm{t})$
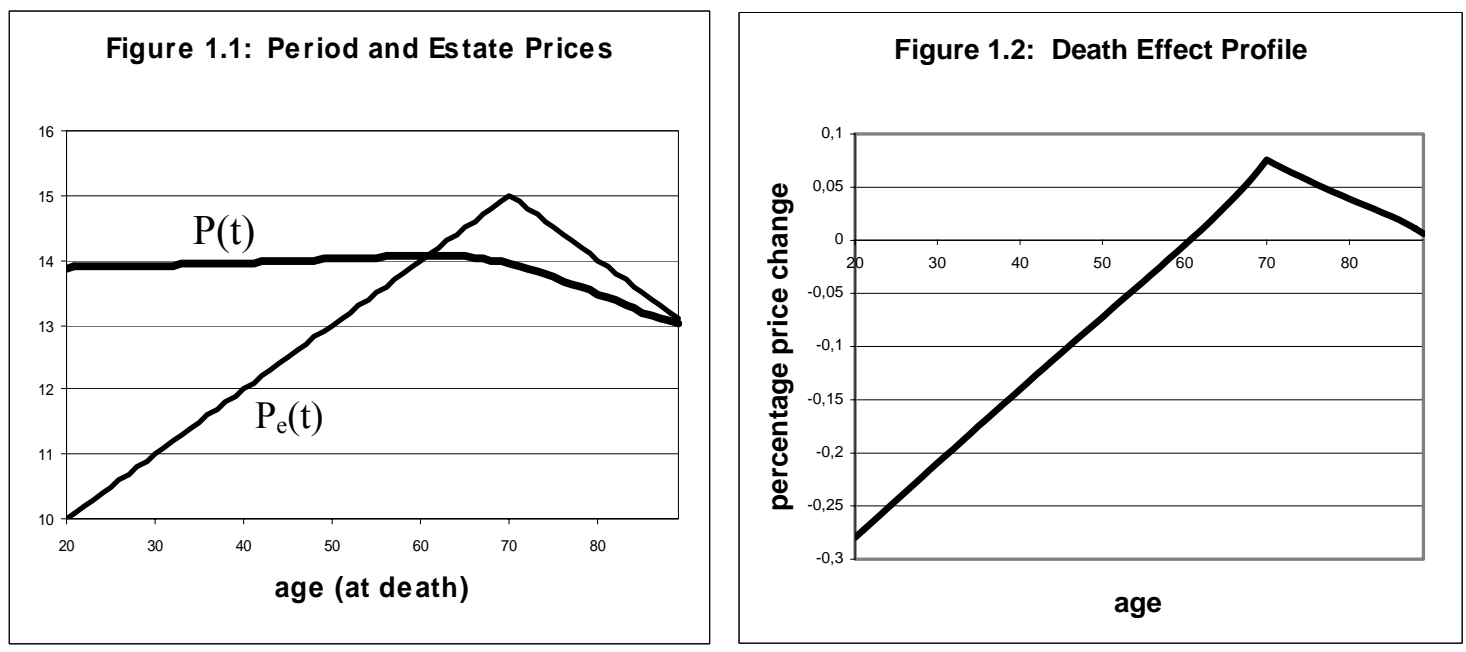

In our example the death effect is negative for artists who die before they reach the age of 60 , and it is positive for artists who die at a greater age. Using the additive structure of our price equation (1), the death effect can easily be decomposed into its two component parts, the reputation effect and the scarcity effect. If art prices were exclusively determined via expected reputation, i.e. if $P_{e}(X)=R(X)$, the death effect $\Delta_{R}(t)$ would be negative and decreasing (in absolute values) up to the critical age at which the artist's reputation reaches the maximum level (in our example at the age of 70). If the artist dies at a greater age, no reputation-related death effect occurs (see Figure 2). On the other hand, if reputation played no role and art prices depended only on expected scarcity, i.e. if $P_{e}(X)=D(X)$, the death effect $\Delta_{\mathrm{D}}(\mathrm{t})$ would be positive and decreasing up to the age at which the artist stops producing

\footnotetext{
${ }^{3}$ We used the period life tables published by the German Office for Statistics. The mortality rates apply to males in the years 1992/94 which mark the middle of our observation period. See http://www.sozialpolitik-aktuell.de/ docs/Periodensterbetafeln.pdf
} 
(in our example at 89). Adding up the reputation and scarcity-related death effects yields the total effect $\Delta(\mathrm{t})$.

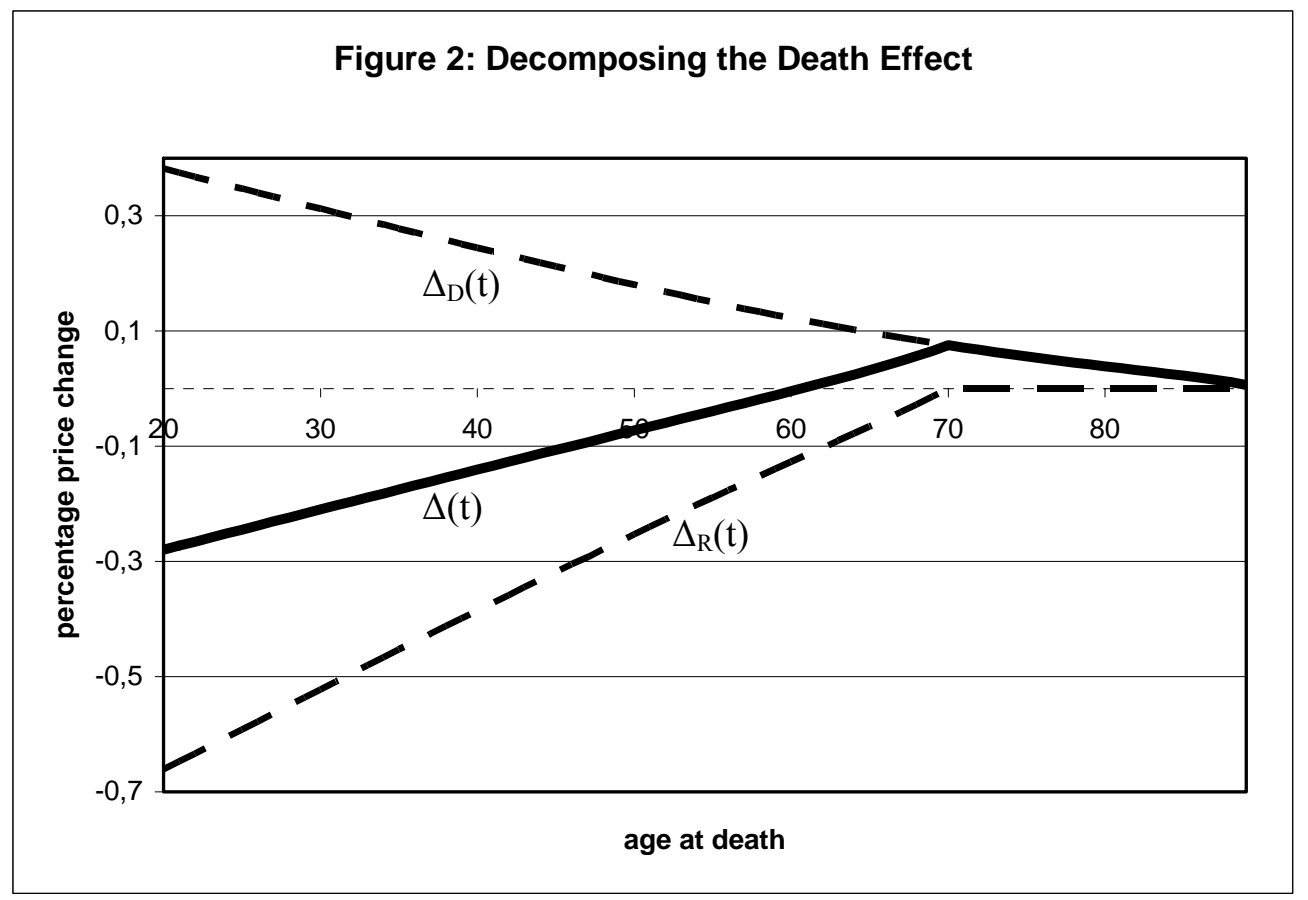

We now turn to analyzing the relationship between the quality of an artist's work and the size of the death effect. To do so, we proceed from two straightforward assumptions concerning the two components of our estate price equation (1). We begin with the function $\mathrm{D}(\mathrm{X})$. Since the work of outstanding artists is, almost by definition, very special, these artists can truly be considered to produce under conditions of monopolistic competition. Less innovative artists, on the other hand, produce artwork that belongs to a specific genre, but is not distinguished by any idiosyncratic creative idea that sets it apart from the production of close competitors. These artists bear a resemblance to mere artisans who produce under market conditions of perfect competition. Prices for artwork created by top artists are thus not only higher than prices for works of art of lesser quality, price sensitivity is also larger. In terms of $\mathrm{D}(\mathrm{X})$ this means that the parameters $a$ and $b$ both vary positively with artistic quality.

The reputation-induced price component $\mathrm{R}(\mathrm{X})$ which portrays the influence of reputation depends on artistic quality as well. Reputation is, after all, directly related to an artist's ability to create truly original works of art. The more novel and ingenious an artist's work is, the more there is to be discovered, the more information about her work can be exchanged and transmitted by the key players and institutions that make up the global art market. It is evident that this reputation-generating mechanism can only properly work if the there is a sufficiently large oeuvre to be promulgated; this is why reputation increases as the artist's oeuvre grows. More important for gaining a sustainable reputation is, however, that the artist's work is sufficiently rich in scope to sustain an ongoing discovery process. In other words, the reputation-generating mechanism feeds on artistic quality. The 
extent to which an increase in the size of an artist's oeuvre $\mathrm{X}$ translates into a gain of reputation $\mathrm{R}$, thus varies positively with the artist's ability to create outstanding works of art, i.e. $d R / d X \equiv r$ increases with artistic quality.

We sum up by concluding that the parameters $a, b$ and $r$ of our estate price equation (1) vary positively with artistic quality. Since the incline of the upward-sloping part of $\mathrm{P}_{\mathrm{e}}(\mathrm{X})$ depends on the difference b$r$, it is not a priori clear whether better artists face steeper or flatter demand curves in the beginning of their careers than their less accomplished colleagues. This ambiguity is however due to our linear specification. A more realistic portrait would assume concave functions $D(X)$ and $R(X)$. Concavity would imply that changes in $R(X)$ translate directly into changes of $P_{e}(X)$ for small values of $X$ since the slope of $\mathrm{D}(\mathrm{X})$ is close to zero at $\mathrm{X}=0$. We therefore assume that higher artistic quality gives rise to steeper demand curves as illustrated in the first panel of Figure 3. The second panel of Figure 3 shows how these differences in artistic quality translate into percentage price changes when the artist dies. This panel also neatly summarizes the five hypotheses that are empirically tested in the remainder of this study.
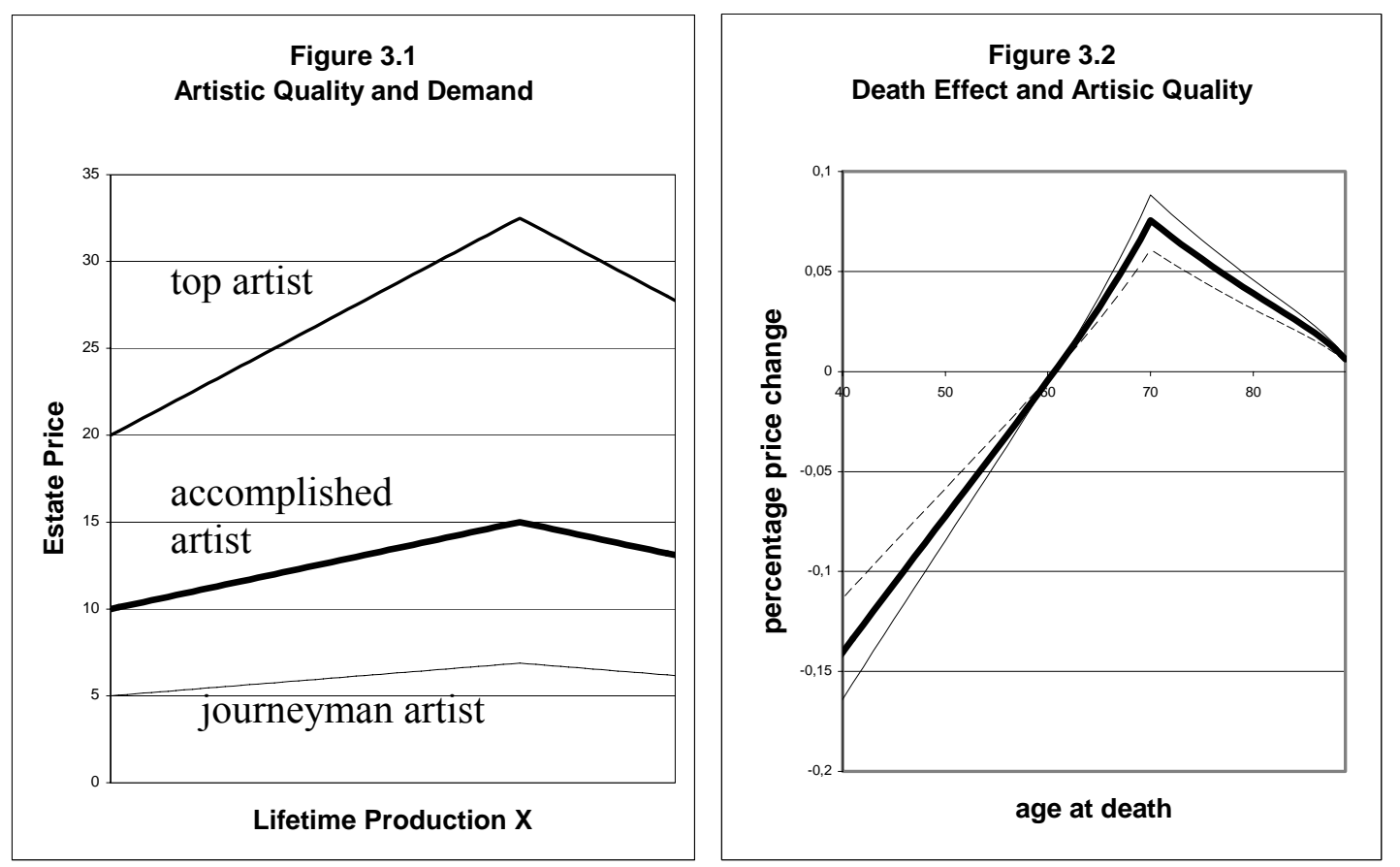

Hypothesis 1: The death effect is a statistically significant phenomenon.

Hypothesis 2: If an artist dies at a relatively young age, the price of her works of art decrease on impact; the price increases however on impact if the artist is lucky enough to live a full life. In other words, for artists dying at a young age, the death effect is dominated by the reputation effect, whereas for artists who die at an old age, the scarcity effect dominates.

\footnotetext{
${ }^{4}$ The bold curve which describes the demand faced by a representative accomplished artist is the one we have used above: $\mathrm{D}_{\mathrm{A}}(\mathrm{X})=10-0.1(\mathrm{t}-20), \mathrm{R}_{\mathrm{A}}(\mathrm{X})=0.2(\mathrm{t}-20)$. Multiplying the intercept and the slopes by $2(1 / 2)$ and then augmenting (diminishing) the absolute value of the slope by $25 \%$ yields the demand curve faced by top-artists (journeymen artists): $\mathrm{D}_{\mathrm{T}}(\mathrm{X})=20-0.25(\mathrm{t}-20), \mathrm{R}_{\mathrm{T}}(\mathrm{X})=0.5(\mathrm{t}-20)$ and $\mathrm{D}_{\mathrm{J}}(\mathrm{X})=5-0.0375(\mathrm{t}-20), \mathrm{R}_{\mathrm{J}}(\mathrm{X})=0.075(\mathrm{t}-20)$.
} 
Hypothesis 3: The relationship between the death effect and the age at death is inversely U-shaped.

Hypothesis 4: The absolute values of the death-induced price changes vary positively with the quality of the deceased artist's work. Since high artistic quality - which we cannot directly observe - gives rise to high prices, this hypothesis implies that the death effect is, ceteris paribus, largest (in absolute values) for artwork fetching high prices.

In focussing our model on the death effect we did not mean to imply that this effect represents a foremost determinant of art price formation. We focussed on the death effect simply because it has hitherto been neglected in the relevant literature, and we readily acknowledge that we are dealing here with a very particular phenomenon by adding

Hypothesis 5: Art prices are determined by many factors. Even though one of the most important determinants, artistic quality, is hard to quantify if resorting to the market price is ruled out, many observable factors such as size, medium, genre, time of sale, etc. do have a significant and systematic influence on art price formation.

\section{Methodology and Dataset}

We test the hypotheses derived in the previous section with the help of hedonic price regressions of the following type:

$$
\ln \mathrm{p}_{\mathrm{it}}=\alpha+\sum_{\mathrm{l}=1}^{\mathrm{m}} \beta_{1} \mathrm{x}_{\mathrm{il}}+\sum_{\mathrm{r}=1}^{\mathrm{s}} \gamma_{\mathrm{r}} \mathrm{y}_{\mathrm{itr}}+\delta_{\mathrm{j}}+\theta_{\mathrm{t}}+\varepsilon_{\mathrm{ijt}},
$$

where $\mathrm{p}_{\mathrm{it}}$ is the real price of artwork i (in 1982 US dollars) sold at time $\mathrm{t}$. The art price is determined by a constant, time-invariant idiosyncratic characteristics $\mathrm{x}_{\mathrm{il}}$ [size, medium, etc.], time-varying characteristics $\mathrm{y}_{\text {itr }}$ [auction house, the flow-supply of the artist's work in a particular year, the artist's state of being alive or dead etc.], artist dummies $\delta_{\mathrm{j}}$ [Picasso, Pollock, Warhol, etc.] capturing the artists' abilities and reputation, and time dummies $\theta_{\mathrm{t}}$ which allow to estimate the influence of the overall art price movement on the price of a specific work of art. These time dummies can also be used to construct a price index for a standardized piece of art. Given the semi-logarithmic specification of our estimation equation (3), the interpretation of the estimated coefficients is straight forward. Percentage changes in the estimated price, given a unit change in, for example, an explanatory variable $\mathrm{x}_{\ell}$, can be calculated as $\Delta \mathrm{p}=\exp \left(\hat{\beta}_{\ell}\right)-1 .{ }^{5}$

The time-dependent variables are of crucial importance for a study investigating the dynamics of art price formation. A first set of time-dependent variables refer to the time when the artwork was created. The date of creation is important because it contains some information about the artwork's genre and

\footnotetext{
${ }^{5}$ This transformation applies since all of our explanatory variables assume discrete values. For continuous variables, the percentage change in the price would be directly reflected by the estimated coefficient.
} 
style which might or might not agree with the contemporary collectors' tastes. Decade dummies seem to be appropriate to capture the style and genre of an artwork. A second set of time-dependent variables is needed to portray the general economic condition and the art market environment at the time of the auction. The boom in the art market in the early 1990 has, for example, been attributed to the bullish stock markets in Japan during that time. We control for changes in the macroeconomic conditions by including "year of sale" variables. A third time-dependent variable that on might want to include is the artist's age at the time of sale or, if the artist is not alive anymore, the length of her life, which, according to our model, can serve as a proxy for the artist's reputation as well as for the scarcity of her oeuvre. Since we include artist-specific dummies, the influence of the length of (productive) life cannot be independently estimated for late artists. For artists who are still alive or have died during our observation period (1980-2005), the age at the time of sale can in principle be included as an explaining variable, at least for those artists whose work has be sold repeatedly during our observation period. Since, however, the maximum time span of 26 years is rather short, we have decided not to use this variable in our preferred specification of the regression. We have, however, run regressions with the artists' age at the time of sale as an explanatory variable. Including this variable has no perceptible influence on our estimates.

It has been argued that an artist's age at the time of creation is related to artistic quality (see Galenson and Weinberg, 2000 and 2001, and Edwards, 2004). One may therefore think that this age should also be included in the regression as an explaining variable. Since, however, the life-cycle creativity patterns are quite diverse, one cannot estimate a common pattern; and classifying hundreds of artists according to whether they have bloomed early in their careers or late, does not appear to be a viable empirical strategy. ${ }^{6}$

To identify the death effect, we make the following distinction:

i. Living artists: if a piece of art created by a living artist is sold, the mean price for her works of art is picked up by the artist's dummy variable $\delta_{\mathrm{j}}$.

ii. Recently deceased artists: if a piece of art created by a recently deceased artist is sold, the price incorporates the death effect. To capture the death effect, we introduce the 0-1 dummy variable Death, which equals unity if the recently deceased artist's work is sold either in year $\mathrm{T}$ in which the artist died, in year $\mathrm{T}+1$, or in year $\mathrm{T}+2$. We have chosen this rather broad time span for two reasons: First, we don't know in which month an artist died. If an artist dies after the fall auctions, the death effect can only be noticed in the following year. Moreover, works of art of some artists are not auctioned each year. To be on the safe side we therefore allow for an additional year for the death effect to be noticed at an auction. Since our theory predicts the death effect to depend on the artists age at death we interact the Death variable with the variable Dage (age at death = death year - birth year) to arrive at

\footnotetext{
${ }^{6}$ Galenson's claim that the life-cycle creativity patterns depend on the artist's production technique has been controversially discussed in the literature (see, for example, Ginsburgh and Weyers, 2006).
} 
the crucial variable $D$-Dage. By estimating polynomials of $D$-Dage of degree three, four and five we are able to identify the sought-after death-effect profiles.

iii. Deceased artists: We control for the evolution of prices beyond the year $\mathrm{T}+2$ by including the explanatory variable TSD which measures the time passed since the artist died. TSD is zero up to T+2. The smallest positive value TSD can assume is thus 3 . This specification assumes that prices evolve in a linear manner for a substantial time after an artist's death. We expect TSD to have a negative influence on prices since dead artists are no longer able to accommodate to the collectors' ever changing tastes.

Before turning to the estimation results, some comments on the employed estimation techniques are called for. We estimate equation (3) by OLS and quantile regressions. The reason for using these two approaches is the following. On the one hand, OLS is computationally less burdensome, which is - given the size of our dataset - clearly an advantage. On the other hand, OLS regressions are vulnerable to outliers, which is a severe drawback since art prices are very heterogeneous. Quantile regressions (cf. Koenker and Bassett, 1978, and Koenker and Hallock, 2000) are less likely to be influenced by extreme outliers since this method minimizes absolute deviations instead of squared deviations. Further advantages of quantile regressions include that they are likely to be more efficient in cases of heteroscedastic data and that one obtains a more differentiated picture of the analyzed price mechanisms.

Our "full" dataset is a selection from Hislop's Art Sales Index (CD-ROM 2005). This database contains art prices for oil paintings, works on paper, prints, sculptures, miniatures and photographs, all collected worldwide from public auctions between 1980 and 2005. From this sample we extracted a sub-sample of 436,308 transaction records for our OLS regressions. We applied five selection criteria: (1) the artwork is a print, a work on paper, or an oil painting; (2) the artwork was sold in the US, Japan, or Western Europe; (3) the birth year and, in case of a deceased artist, the death year are known; (4) the year of creation of the artwork is after 1873 and known; ${ }^{7}(5)$ height and width of the artwork are known.

Computational limitations forced us to further restrict the sample size for our quantile regressions. To arrive at a manageable sample size we deleted all minor artists, defined as those artists whose works of art were auctioned less than 250 times in the sample period 1980-2005. Applying this admittedly arbitrary rule significantly reduces the number of artist from 25,204 to 262 [thus reducing the number of artist dummies], while preserving a relatively large number of observations $(146,575)$.

A detailed description of the employed variables and summary statistics for both datasets are reported in the Appendix.

\footnotetext{
${ }^{7}$ This year was chosen since it roughly marks the beginning of impressionism.
} 


\section{First results}

In Table 1 we report the results of three OLS regressions of equation (3). The death effect is estimated by a third-order polynomial of the variable D-Dage. Estimates of higher-order polynomials are discussed below. The first column reports the results using our full data set. Since our auction records cover the period 1980-2005, the estimated death effects relate to artists who died during this period. The second regression is based on a sub-sample of the full dataset which excludes works of art by artists who were already dead by 1980 . The third regression only considers works of art by artists who died between 1980 and 2005.

Before elaborating on the estimated death effects in the following section, we discuss here the estimates of the other coefficients.

i. Medium: It is well known that different types of artwork fetch different prices. Our results confirm this. Oil on canvas yields the highest prices ( $+410 \%$ as compared to prints), followed by drawings on paper $(+80 \%)$ and prints.

ii. Size: We allow for different size effects for oil paintings, drawings on paper, and prints. We make this distinction since large prints are an exception, whereas artists sometimes create extraordinary large paintings and drawings. Our estimates confirm our conjecture that size effects differ across the three media. For prints we find a stable linear relationship between size and price. An increase in height (width) by $10 \mathrm{~cm}$ raises the price of a print by about $7.2 \%(3.9 \%)$. For oil paintings and drawings on paper, the estimates of the squared regressors become significant. Prices of "reasonably" sized pictures vary positively with size. As one would expect, prices do, however, decline beyond a critical size. This critical size appears to be determined by wall sizes in ordinary collectors' homes. Paintings and drawings exceeding these dimensions are mainly bought by museums, whose demand is limited. To be more specific: prices of oil paintings increase up to a size of roughly $2.5 \times 4 \mathrm{~m}$ (height $\times$ width), but decline for larger dimensions. The same holds for works on paper whose optimal size in terms of revenue is $3.2 \times 3.8 \mathrm{~m}$.

iii. Signature: A signature is a sign of authenticity. As expected, prices increase by roughly $+27 \%$ if a work of art is signed. Our estimate is thus in line with the commonly held belief, but contradicts the finding by Czujack (1997) who cannot detect any positive influence of a signature on the price of Picasso's works of art. We will return to this issue in the next section when we elaborate on the estimates of our quantile regressions. 
Table 1: OLS regressions, $3^{\text {rd }}$-ordere polynomial of D-Dage

\begin{tabular}{|c|c|c|c|c|c|c|}
\hline & \multicolumn{2}{|c|}{ full sample } & \multicolumn{2}{|c|}{ year at death $>1979$} & \multicolumn{2}{|c|}{$2006>$ year at death $>1979$} \\
\hline LNPRICE & coeff. & SE & coeff. & SE & coeff. & SE \\
\hline Oil & $1.6291 * * *$ & 0.013 & $1.6200 * * *$ & 0.019 & $1.6745 * * *$ & 0.025 \\
\hline OilHeight & $1.1492 * * *$ & 0.013 & $1.0107 * * *$ & 0.015 & $0.9892 * * *$ & 0.021 \\
\hline OilHeightS & $-0.2352 * * *$ & 0.004 & $-0.1859 * * *$ & 0.005 & $-0.1463 * * *$ & 0.006 \\
\hline OilWidth & $0.8587 * * *$ & 0.010 & $0.8034 * * *$ & 0.012 & $0.8804 * * *$ & 0.018 \\
\hline OilWidthS & $-0.1121^{* * *}$ & 0.002 & $-0.0999 * * *$ & 0.003 & $-0.1060 * * *$ & 0.004 \\
\hline Paper & $0.5912 * * *$ & 0.012 & $0.7995 * * *$ & 0.019 & $0.7117 * * *$ & 0.024 \\
\hline PaperHeight & $1.3041 * * *$ & 0.018 & $1.1532 * * *$ & 0.021 & $1.2826^{* * *}$ & 0.037 \\
\hline PaperHeightS & $-0.2021^{* * *}$ & 0.006 & $-0.1621^{* * *}$ & 0.006 & $-0.1808^{* * *}$ & 0.014 \\
\hline PaperWidth & $1.2625^{* * *}$ & 0.016 & $0.9817 * * *$ & 0.019 & $1.0548 * * *$ & 0.032 \\
\hline PaperWidthS & $-0.1680 * * *$ & 0.004 & $-0.1088^{* * *}$ & 0.005 & $-0.0832 * * *$ & 0.009 \\
\hline PrintHeight & $0.5445^{* * *}$ & 0.019 & $0.4751 * * *$ & 0.021 & $0.3669 * * *$ & 0.032 \\
\hline PrintWidth & $0.3298 * * *$ & 0.017 & $0.3890 * * *$ & 0.018 & $0.2845^{* * *}$ & 0.026 \\
\hline Signature & $0.1380 * * *$ & 0.005 & $0.0603 * * *$ & 0.007 & $0.1067 * * *$ & 0.009 \\
\hline Supply & $-0.0004 * * *$ & 0.000 & $0.0007 * * *$ & 0.000 & $0.0006^{* * *}$ & 0.000 \\
\hline US & $-0.1348 * * *$ & 0.010 & $-0.1407 * * *$ & 0.014 & $-0.1182 * * *$ & 0.019 \\
\hline JAP & $0.2984 * * *$ & 0.107 & -0.0190 & 0.130 & 0.0616 & 0.137 \\
\hline SOLO & $0.4973 * * *$ & 0.006 & $0.4260 * * *$ & 0.009 & $0.3848 * * *$ & 0.012 \\
\hline SOPA & $0.2839 * * *$ & 0.056 & $0.3279 * * *$ & 0.068 & $0.2557 * * *$ & 0.096 \\
\hline SONY & $0.5808^{* * *}$ & 0.007 & $0.5120 * * *$ & 0.009 & $0.4919 * * *$ & 0.013 \\
\hline SOEU & $0.1482 * * *$ & 0.008 & $0.1600 * * *$ & 0.011 & $0.1264 * * *$ & 0.015 \\
\hline SOUS & $-0.0928 * * *$ & 0.017 & $-0.1019 * * *$ & 0.022 & $-0.1340 * * *$ & 0.032 \\
\hline CHLO & $0.5851 * * *$ & 0.007 & $0.4663 * * *$ & 0.010 & $0.4837 * * *$ & 0.013 \\
\hline CHPA & $0.1489 * * *$ & 0.042 & $0.1964 * * *$ & 0.052 & $0.1965 * * *$ & 0.071 \\
\hline CHNY & $0.5339 * * *$ & 0.008 & $0.4983 * * *$ & 0.010 & $0.4685 * * *$ & 0.015 \\
\hline CHEU & $0.0697 * * *$ & 0.007 & $0.0590 * * *$ & 0.009 & $0.0546^{* * *}$ & 0.013 \\
\hline CHUS & $0.4080^{* * *}$ & 0.009 & $0.3485^{* * *}$ & 0.011 & $0.3766^{* * *}$ & 0.015 \\
\hline NY & $0.0806^{* * *}$ & 0.011 & $0.0944 * *$ & 0.016 & $0.0552 * *$ & 0.022 \\
\hline LO & $0.1759 * * *$ & 0.011 & $0.1401 * * *$ & 0.017 & $0.1463 * * *$ & 0.023 \\
\hline PA & $0.0235 * * *$ & 0.006 & -0.0054 & 0.007 & -0.0155 & 0.010 \\
\hline ay1981 & $-0.0578 * * *$ & 0.014 & $-0.0659 * *$ & 0.024 & $-0.0734^{* *}$ & 0.031 \\
\hline ay1982 & $-0.1767 * * *$ & 0.015 & $-0.1881 * * *$ & 0.025 & $-0.2118 * * *$ & 0.033 \\
\hline ay1983 & $-0.0975^{* * *}$ & 0.015 & $-0.0997 * * *$ & 0.023 & $-0.0961 * * *$ & 0.031 \\
\hline ay1984 & $-0.0639 * * *$ & 0.014 & $-0.0906 * * *$ & 0.022 & $-0.0960 * * *$ & 0.029 \\
\hline ay1985 & $0.0668 * * *$ & 0.014 & 0.0351 & 0.021 & 0.0257 & 0.028 \\
\hline ay1986 & $0.3571 * * *$ & 0.014 & $0.3400 * * *$ & 0.021 & $0.3221 * * *$ & 0.028 \\
\hline ay1987 & $0.7531 * * *$ & 0.013 & $0.7281 * * *$ & 0.020 & $0.7155^{* * *}$ & 0.027 \\
\hline ay1988 & $1.0062 * * *$ & 0.013 & $0.9823 * * *$ & 0.020 & $0.9952 * * *$ & 0.026 \\
\hline ay1989 & $1.3287 * * *$ & 0.013 & $1.3681 * * *$ & 0.019 & $1.3579 * * *$ & 0.025 \\
\hline ay1990 & $1.4708 * * *$ & 0.013 & $1.5328 * * *$ & 0.019 & $1.5223 * * *$ & 0.025 \\
\hline ay1991 & $1.0701 * * *$ & 0.014 & $1.1064 * * *$ & 0.020 & $1.0888 * * *$ & 0.027 \\
\hline ay1992 & $0.9627 * * *$ & 0.014 & $0.9854 * * *$ & 0.020 & $0.9844 * * *$ & 0.027 \\
\hline ay1993 & $0.8182 * * *$ & 0.013 & $0.8304 * * *$ & 0.020 & $0.8434 * * *$ & 0.027 \\
\hline ay1994 & $0.8117 * * *$ & 0.013 & $0.8360 * * *$ & 0.019 & $0.8656 * * *$ & 0.026 \\
\hline ay1995 & $0.8692 * * *$ & 0.013 & $0.8534 * * *$ & 0.019 & $0.8832 * * *$ & 0.027 \\
\hline ay1996 & $0.8555 * * *$ & 0.013 & $0.8299 * * *$ & 0.019 & $0.8750 * * *$ & 0.026 \\
\hline ay1997 & $0.8434 * * *$ & 0.013 & $0.7994 * * *$ & 0.019 & $0.8409 * * *$ & 0.026 \\
\hline ay1998 & $0.9071 * * *$ & 0.014 & $0.8746^{* * *}$ & 0.019 & $0.9152 * * *$ & 0.027 \\
\hline ay1999 & $0.9357 * * *$ & 0.014 & $0.8998 * * *$ & 0.019 & $0.9453 * * *$ & 0.027 \\
\hline
\end{tabular}




\begin{tabular}{|c|c|c|c|c|c|c|}
\hline LNPRICE & coeff. & SE & coeff. & SE & coeff. & SE \\
\hline ay2000 & $0.9293 * * *$ & 0.014 & $0.8884 * * *$ & 0.019 & $0.9494 * * *$ & 0.027 \\
\hline ay2001 & $0.8911 * * *$ & 0.014 & $0.8669 * * *$ & 0.019 & $0.9385 * * *$ & 0.028 \\
\hline ay2002 & $0.9800^{* * *}$ & 0.014 & $0.9749 * * *$ & 0.019 & $1.0528 * * *$ & 0.029 \\
\hline ay2003 & $1.1274 * * *$ & 0.014 & $1.1346 * * *$ & 0.019 & $1.2146^{* * *}$ & 0.029 \\
\hline ay2004 & $1.2959 * * *$ & 0.015 & $1.3010 * * *$ & 0.019 & $1.3795 * * *$ & 0.030 \\
\hline ay2005 & $1.4383 * * *$ & 0.016 & $1.4923 * * *$ & 0.020 & $1.5687 * * *$ & 0.032 \\
\hline $\operatorname{cdec} 1870$ & $-0.1408^{* *}$ & 0.067 & & & & \\
\hline $\operatorname{cdec} 1880$ & $0.3680 * * *$ & 0.028 & & & & \\
\hline $\operatorname{cdec} 1890$ & $0.3208 * * *$ & 0.024 & 0.3234 & 0.386 & 0.4578 & 0.406 \\
\hline cdec1900 & $0.3454 * * *$ & 0.022 & $0.4456^{* * *}$ & 0.096 & $0.6210 * * *$ & 0.128 \\
\hline cdecy 1910 & $0.3627 * * *$ & 0.021 & $0.4029 * * *$ & 0.033 & $0.5378 * * *$ & 0.087 \\
\hline cdecy 1920 & $0.2652 * * *$ & 0.021 & $0.2614 * * *$ & 0.023 & $0.4127 * * *$ & 0.084 \\
\hline cdec1930 & $0.1997 * * *$ & 0.021 & $0.2662 * * *$ & 0.021 & $0.4185^{* * *}$ & 0.083 \\
\hline cdec 1940 & $0.1576 * * *$ & 0.021 & $0.2243 * * *$ & 0.020 & $0.3851 * * *$ & 0.083 \\
\hline cdec 1950 & $0.0581 * * *$ & 0.021 & $0.1106^{* * *}$ & 0.019 & $0.2481 * * *$ & 0.083 \\
\hline cdec 1960 & $-0.0568 * * *$ & 0.020 & -0.0236 & 0.019 & 0.1026 & 0.083 \\
\hline cdec 1970 & $-0.1591 * * *$ & 0.020 & $-0.1361 * * *$ & 0.019 & 0.0042 & 0.083 \\
\hline cdec 1980 & $-0.1903 * * *$ & 0.020 & $-0.1544 * * *$ & 0.019 & -0.0267 & 0.083 \\
\hline cdec 1990 & $-0.1119 * * *$ & 0.020 & $-0.0899 * * *$ & 0.018 & -0.0257 & 0.083 \\
\hline TSD & $-0.0037 * * *$ & 0.000 & $-0.0119 * * *$ & 0.001 & $-0.0164 * * *$ & 0.001 \\
\hline D-Dage & $-0.0277 * * *$ & 0.003 & $-0.0301 * * *$ & 0.003 & $-0.0325 * * *$ & 0.003 \\
\hline D-Dage2 & $0.6935^{* * *}$ & 0.088 & $0.7341^{* * *}$ & 0.082 & $0.7852 * * *$ & 0.085 \\
\hline D-Dage3 & $-0.0042 * * *$ & 0.001 & $-0.0044 * * *$ & 0.001 & $-0.0047 * * *$ & 0.001 \\
\hline Constant & $4.9865^{* * *}$ & 0.026 & $4.8783^{* * *}$ & 0.032 & $4.9176^{* * *}$ & 0.089 \\
\hline $\begin{array}{l}\text { Observations } \\
\mathrm{R}^{2}\end{array}$ & \multicolumn{2}{|l|}{$\begin{array}{l}436,308 \\
0.7594\end{array}$} & \multicolumn{2}{|l|}{$\begin{array}{l}213,528 \\
0.7729\end{array}$} & \multicolumn{2}{|l|}{$\begin{array}{l}109,659 \\
0.7624\end{array}$} \\
\hline
\end{tabular}

iv. Supply: One would expect the actual supply of an artist's work (as measured by the number of pieces auctioned in the respective year) to decrease the market price of her works of art. This expectation is based on the conviction that most collectors are merely interested in owning a representative piece of a certain artist rather than a specific piece. Our estimates indeed indicate that an additional supply of 10 pieces per year reduces the market price by about $0.5 \%$. Although this effect is not very large, it indicates that an unusually large actual supply tends to depress prices, or, vice versa, higher prices are fetched in thin markets.

v. Country of Sale and Auction House: The influence of the country of sale and of specific salerooms is summarized in Figure 4. 
Figure 4: Country of Sale and Auction House (full sample)

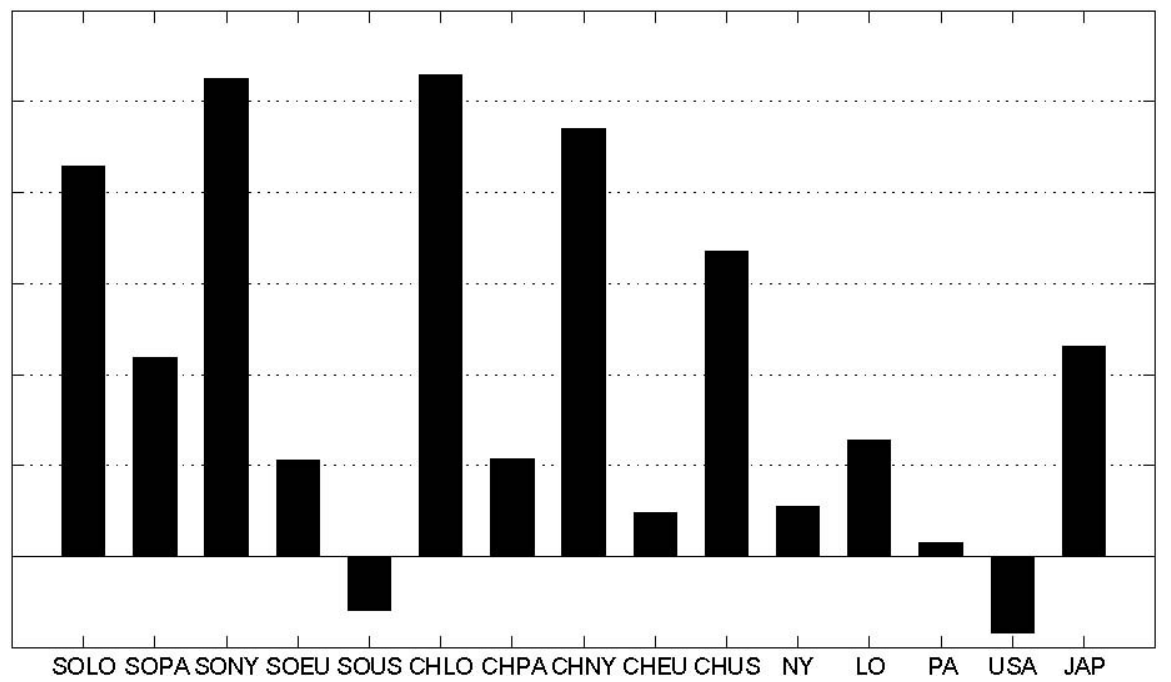

All percentage price changes reported in Figure 4 are with respect to a work of art sold in Europe, but not at Sotheby's or Christie's, and not in London or Paris. Sales at Sotheby's New York [+79\%] yield higher prices than sales at Sotheby's London [+64\%], Sotheby's Paris [+33\%], and Sotheby's salerooms in the remaining Europe [+15\%]. Sales at Sotheby's US excluding New York fetch even less [-9\%]. Unlike Sotheby's, Christie's auctions achieve higher prices in London [+80\%] than in New York $[+71 \%]$, the rest of the US [+50\%], Paris [+17\%], and the remaining Europe [+7\%]. Apart from the two predominant auction houses, we find that prices in London $[+19 \%]$ are higher than in New York [+8\%] and Paris [+2\%], and sales in Japan [+35\%] fetch more than sales in Europe and the United States $[-13 \%] .^{8}$

vi. Price Index: The hedonic art price index which results from the estimated coefficients of the yeardummies is depicted in the first panel of Figure 5. Our result is well in line with previous findings (see, for example, Ashenfelter and Graddy, 2006). In the year 2005 the art prices reached again the level of the last arts market boom in 1990. During the 1990's prices had been rather low and constant.

\footnotetext{
8 These estimates reconfirm previous results indicating that the law of one price does not hold in the arts market (see, for example, Ashenfelter and Graddy, 2006, Pesando, 1993, Pesando and Shum, 1996, and Mei and Moses, 2002). Notice, however, that the estimated differences may be somewhat biased. Certain auction houses and salerooms appear to attracts works of art of superior quality, which increases the average price. Our regressions cannot completely control for this influence, because there are, for example, hardly any Picasso paintings sold at auction houses not located in Paris, London or New York. The high prices in Japan, moreover, seem to be driven, at least to some extent, by peculiarities in the data collection process. Japanese sales appear to be underrepresented in Hislop's Art Sales Index and the reported prices are extraordinarily high. We conjecture that the Japanese data may be incomplete with respect to the bottom of the distribution.
} 
Figure 5: Hedonic Art Price Index, 1980 -2005, and Creation Period Index, sample 1
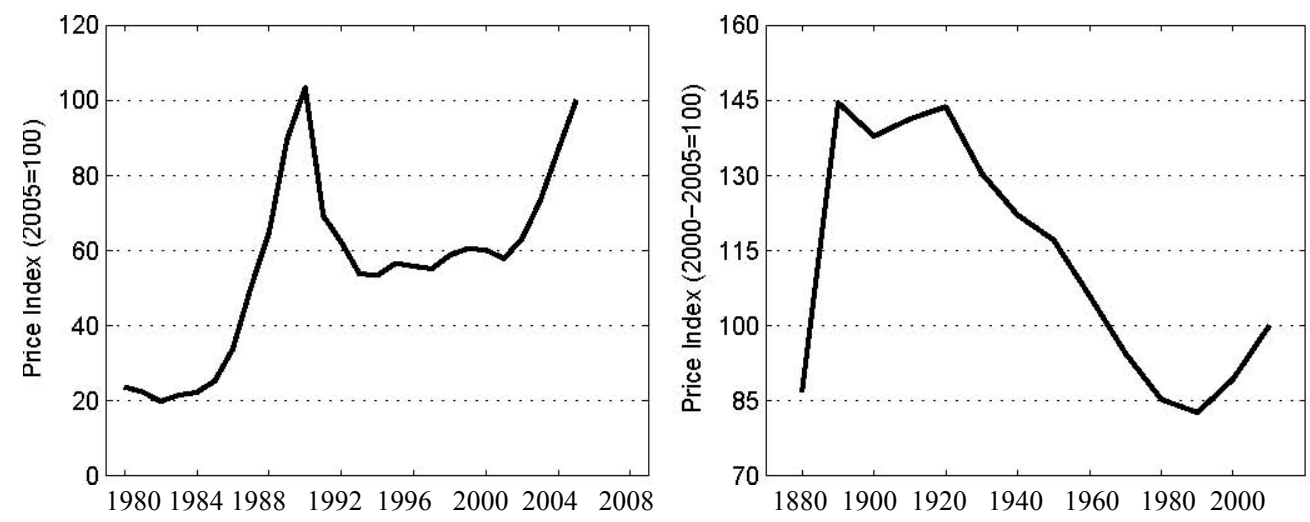

vii. Genre: The decade in which a work of art has been created is not merely an indicator of age but foremost an indicator of contemporary collectors' tastes for certain periods and genres. The estimated coefficients of the decade dummy variables thus reveal which periods were en vogue during our observation period (1980-2005). The results are summarized in the second panel of Figure 5. Works of art from the period 1890-1920 fetch the highest prices. Prices for works from subsequent periods vary positively with age; only the most recent batch appears to escape this rule, conceivably because contemporary artists are able to produce exactly that kind of art that meets the contemporary collectors' tastes.

All things considered, these results lend strong support to our Hypothesis 5. To be sure, this hypothesis is a For our quantile regressions simple restatement of the received wisdom. It is, however, worth mentioning again that we have confirmed these results with a dataset that is by an order of magnitude larger than the datasets that have hitherto been used in the relevant literature.

\section{The Death-Effect}

\subsection{OLS Regressions}

In this section we discuss the estimation results relating to our hypotheses on the death effect. We begin with the results of our OLS regressions. Table 2 reports the estimates of nine different OLS regressions. The first set of results corresponds to the estimates already shown in Table 1 ( $3^{\text {rd }}$-order polynomials of $D$-Dage). The estimates of the forth- and fifth-order polynomials of the variable $D$ Dage are taken from regressions using the same set of explaining variables. 
Table 2:Comparison of different D-Dage polynomials (OLS)

\begin{tabular}{|c|c|c|c|}
\hline LNPRICE & \multicolumn{3}{|c|}{$3^{\text {rd }}$-order polynomials } \\
\hline & Full Sample & year at death $>1979$ & $2006>$ year at death $>1979$ \\
\hline D-Dage & $-0.0277101 * * *$ & $-0.0301143 * * *$ & $-0.0324680 * * *$ \\
\hline D-DageS & $0.6934739 * * *$ & $0.7341452 * * *$ & $0.7851855^{* * *}$ \\
\hline D-DageT & $-0.0041586^{* * *}$ & $-0.0043546^{* * *}$ & $-0.0046578 * * *$ \\
\hline \multirow{4}{*}{$\begin{array}{l}\text { Adj. } \mathrm{R}^{2} \\
\mathrm{R}^{2} \\
\text { Observations }\end{array}$} & 0.7594 & 0.7729 & 0.7624 \\
\hline & 0.7446 & 0.7568 & 0.7534 \\
\hline & 436,308 & 213,528 & 109,659 \\
\hline & \multicolumn{3}{|c|}{$4^{\text {th }}$-order polynomials } \\
\hline D-Dage & $-0.0326757 * * *$ & $-0.0452921 * * *$ & $-0.0449829 * * *$ \\
\hline D-DageS & $0.9146908^{* *}$ & $1.4105710 * * *$ & $1.3427720^{* * *}$ \\
\hline D-DageT & -0.0073107 & $-0.0139974 * * *$ & $-0.0126044 * *$ \\
\hline D-DageQ & 0.0000145 & $0.0000444 *$ & 0.0000366 \\
\hline Adj. $\mathrm{R}^{2}$ & 0.7594 & 0.7729 & 0.7624 \\
\hline $\mathrm{R}^{2}$ & 0.7446 & 0.7568 & 0.7534 \\
\hline \multirow[t]{2}{*}{ Observations } & 436,308 & 213,528 & 109,659 \\
\hline & \multicolumn{3}{|c|}{$5^{\text {th }}$-order polynomials } \\
\hline D-Dage & $-0.1065902 * * *$ & $-0.1223569 * * *$ & $-0.1191484 * * *$ \\
\hline D-Dages & $5.7491710^{* * *}$ & $6.4534790 * * *$ & $6.1952460 * * *$ \\
\hline D-DageT & $-0.1188100 * * *$ & $-0.1303223 * * *$ & $-0.1245290 * * *$ \\
\hline D-DageQ & $0.0011069^{* * *}$ & $0.0011840 * * *$ & $0.0011330 * * *$ \\
\hline D-DageP & $-0.0000039 * * *$ & $-0.0000040^{* * *}$ & $-0.0000039 * * *$ \\
\hline Adj. $\mathrm{R}^{2}$ & 0.7594 & 0.7729 & 0.7624 \\
\hline & 0.7447 & 0.7568 & 0.7535 \\
\hline Observations & 436,308 & 213,528 & 109,659 \\
\hline
\end{tabular}

It turns out that the results across all regressions are very similar and confirm the statistical significance of the death effect (Hypothesis 1). The fourth-order polynomial is, however, statistically somewhat less significant. The adjusted- $\mathrm{R}^{2}$ statistics do not differ across the three different specifications which leaves us with a difficult choice with respect to the preferred specification. We also performed F-tests for the significance of the highest-order term of the polynomials. Even though the last terms D-DageP of the fifth-order polynomials is rather small, the F-tests nevertheless indicate that these coefficients are statistically different from zero. Since we do not have a preferred specification, we show in Figure 6 the respective plots for all nine regressions. 
Figure 6: Death effect for different ages at death

(sample 1: dashed line, sample 2: solid line, sample 3: starred line)
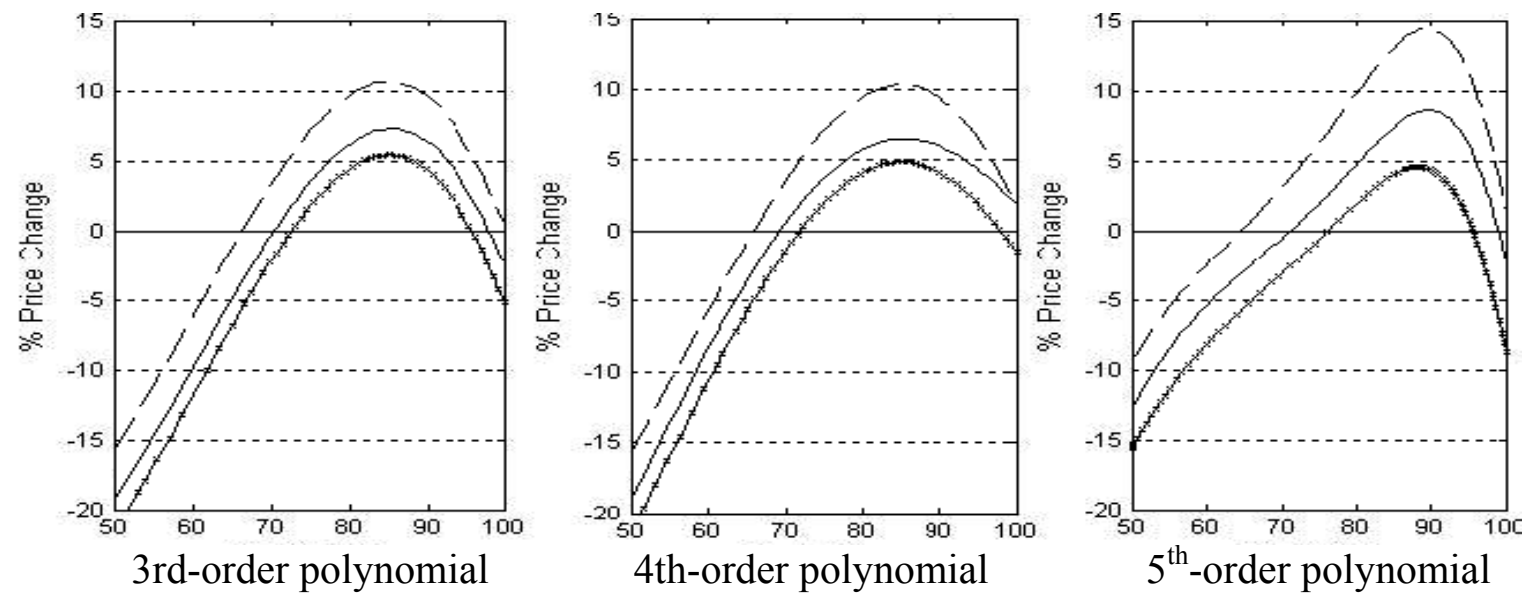

All nine graphs have the same appearance: the relationship between the death effect and the age at death is inverted U-shaped, thereby confirming our third hypothesis. Also our second hypothesis passes the test with flying colours: the death effect is indeed negative if an artist dies at a young age. This negative impact decreases with increasing age at death, and the death effect completely disappears - depending on the specification - between the age of 63 and 75. If the artist dies after that critical age, the reputation effect is dominated by the scarcity effect and the death effect becomes positive. The death effect is at a maximum for an age at death between 83 and 88 years and amounts to $11 \%-14 \%$. At greater ages at death, the effect appears to decrease again, and for some of the estimates we even obtain negative values. We do, however, not want to belabour this last point because borders of polynomials need to be interpreted with care, especially if they are determined by a rather small number of data points.

\subsection{Quantile Regressions}

We now turn to the quantile regressions which serve as a robustness check of our OLS results. Moreover, they allow us to test our Hypothesis 4. As already mentioned above, we need, for computational reasons, to restrict the analysis to a relatively small group of artists, and we do so by including only those artists whose artwork has been sold more than 250 times. We report only regressions using $3^{\text {rd }}$-order polynomials of the variable D-Dage since the OLS regressions have indicated that including higher-order polynomials has no notable effect on the estimates. ${ }^{9}$

\footnotetext{
${ }^{9}$ We have, however, checked the robustness of our results using both fourth- and fifth-order polynomials.
} 
Table 3: Quantile Regressions, $3^{\text {rd }}$ - order polynomials of $D$-Dage

\begin{tabular}{|c|c|c|c|c|c|c|c|c|c|c|}
\hline & \multicolumn{2}{|c|}{$10 \%$ Quantile } & \multicolumn{2}{|c|}{ 25\% Quantile } & \multicolumn{2}{|c|}{ 75\% Quantile } & \multicolumn{2}{|c|}{ 90\% Quantile } & \multicolumn{2}{|c|}{ OLS } \\
\hline LNPRICE & Coeff. & $\mathrm{SE}$ & Coeff. & SE & Coeff. & $\mathrm{SE}$ & Coeff. & $\mathrm{SE}$ & Coeff. & SE \\
\hline Oil & $0.9844 * * *$ & 0.03 & $1.4328 * * *$ & 0.02 & $1.9915 * * *$ & 0.02 & $2.0301 * * *$ & 0.04 & $1.7752 * * *$ & 0.018 \\
\hline OilHeight & $1.6513 * * *$ & 0.03 & $1.7979 * * *$ & 0.03 & $2.0115 * * *$ & 0.04 & $2.0818 * * *$ & 0.07 & $1.7080 * * *$ & 0.028 \\
\hline OilHeightS & $-0.4833 * * *$ & 0.01 & $-0.5142 * * *$ & 0.01 & $-0.5482 * * *$ & 0.02 & $-0.5437 * * *$ & 0.03 & $-0.4164 * * *$ & 0.010 \\
\hline OilWidth & $1.0379 * * *$ & 0.03 & $1.0197 * * *$ & 0.02 & $0.8542 * * *$ & 0.03 & $0.7756 * * *$ & 0.04 & $0.8464 * * *$ & 0.020 \\
\hline OilWidthS & $-0.1679 * * *$ & 0.00 & $-0.1612 * * *$ & 0.00 & $-0.1048 * * *$ & 0.01 & $-0.0770 * * *$ & 0.01 & $-0.1027 * * *$ & 0.004 \\
\hline Paper & $-0.2069 * * *$ & 0.03 & $0.1784 * * *$ & 0.02 & $0.8229 * * *$ & 0.02 & $0.9194 * * *$ & 0.03 & $0.5098 * * *$ & 0.016 \\
\hline PaperHeight & $1.5160 * * *$ & 0.04 & $1.7434 * * *$ & 0.03 & $1.8335 * * *$ & 0.04 & $1.8058 * * *$ & 0.08 & $1.5616 * * *$ & 0.030 \\
\hline PaperHeightS & $-0.4024 * * *$ & 0.01 & $-0.4640 * * *$ & 0.01 & $-0.3880 * * *$ & 0.02 & $-0.3092 * * *$ & 0.04 & $-0.2723 * * *$ & 0.010 \\
\hline PaperWidth & $1.9477 * * *$ & 0.04 & $1.9906 * * *$ & 0.03 & $1.6748 * * *$ & 0.04 & $1.5333 * * *$ & 0.06 & $1.7191 * * *$ & 0.030 \\
\hline PaperWidthS & $-0.5198 * * *$ & 0.01 & $-0.5148 * * *$ & 0.01 & $-0.3221 * * *$ & 0.02 & $-0.2380 * * *$ & 0.03 & $-0.3331 * * *$ & 0.009 \\
\hline PrintHeight & $0.3252 * * *$ & 0.05 & $0.4413 * * *$ & 0.03 & $0.5871 * * *$ & 0.03 & $0.6723 * * *$ & 0.04 & $0.5291 * * *$ & 0.024 \\
\hline PrintWidth & $0.2120 * * *$ & 0.05 & $0.3885 * * *$ & 0.03 & $0.6717 * * *$ & 0.03 & $0.6614 * * *$ & 0.03 & $0.4053 * * *$ & 0.022 \\
\hline Signature & $0.2516 * * *$ & 0.01 & $0.2391 * * *$ & 0.01 & $0.1628 * * *$ & 0.01 & $0.1064 * * *$ & 0.01 & $0.2289 * * *$ & 0.008 \\
\hline Supply & $-0.0004 * * *$ & 0.00 & $-0.0005 * * *$ & 0.00 & $-0.0002 * * *$ & 0.00 & $-0.0001 *$ & 0.00 & $-0.0003 * * *$ & 0.000 \\
\hline US & $-0.2607 * * *$ & 0.03 & $-0.2266 * * *$ & 0.02 & $-0.2546 * * *$ & 0.02 & $-0.2030 * * *$ & 0.03 & $-0.2605 * * *$ & 0.019 \\
\hline JAP & $0.4300 * * *$ & 0.16 & $0.4625 * * *$ & 0.13 & 0.1275 & 0.15 & -0.1477 & 0.18 & $0.2849 * *$ & 0.117 \\
\hline SOLO & $0.4191 * * *$ & 0.01 & $0.3789 * * *$ & 0.01 & $0.3264 * * *$ & 0.01 & $0.3390 * * *$ & 0.01 & $0.4283 * * *$ & 0.009 \\
\hline SOPA & $0.1963 *$ & 0.12 & $0.2179 *$ & 0.09 & -0.0441 & 0.11 & -0.1856 & 0.13 & 0.1301 & 0.087 \\
\hline SONY & $0.4439 * * *$ & 0.01 & $0.4305 * * *$ & 0.01 & $0.4447 * * *$ & 0.01 & $0.4747 * * *$ & 0.01 & $0.5295 * * *$ & 0.010 \\
\hline SOEU & $0.1450 * * *$ & 0.02 & $0.0718 * * *$ & 0.02 & $0.1009 * * *$ & 0.02 & $0.0864 * * *$ & 0.02 & $0.0970 * * *$ & 0.015 \\
\hline SOUS & $-0.1465 * * *$ & 0.04 & $-0.2003 * * *$ & 0.04 & $-0.2118 * * *$ & 0.04 & $-0.2564 * * *$ & 0.05 & $-0.2252 * * *$ & 0.032 \\
\hline CHLO & $0.4825 * * *$ & 0.01 & $0.4436 * * *$ & 0.01 & $0.4145 * * *$ & 0.01 & $0.4301 * * *$ & 0.02 & $0.5299 * * *$ & 0.010 \\
\hline CHPA & $0.1782 *$ & 0.09 & $0.1980 * * *$ & 0.07 & 0.0972 & 0.09 & 0.0966 & 0.10 & $0.1473 * *$ & 0.068 \\
\hline CHNY & $0.4608 * * *$ & 0.02 & $0.4304 * * *$ & 0.01 & $0.4276 * * *$ & 0.01 & $0.4405 * * *$ & 0.02 & $0.5255 * * *$ & 0.011 \\
\hline CHEU & 0.0062 & 0.02 & -0.0136 & 0.01 & -0.0062 & 0.02 & -0.0074 & 0.02 & -0.0131 & 0.013 \\
\hline CHUS & $0.2708 * * *$ & 0.02 & $0.2625 * * *$ & 0.01 & $0.3234 * * *$ & 0.01 & $0.4125 * * *$ & 0.02 & $0.3796 * * *$ & 0.012 \\
\hline NY & 0.0067 & 0.02 & -0.0205 & 0.02 & $-0.0598 * * *$ & 0.02 & 0.0412 & 0.03 & -0.0119 & 0.018 \\
\hline LO & $0.1467 * * *$ & 0.03 & $0.1147 * * *$ & 0.02 & $0.0984 * * *$ & 0.03 & $0.1386 * * *$ & 0.03 & $0.1531 * * *$ & 0.022 \\
\hline PA & $-0.0320 * * *$ & 0.01 & -0.0036 & 0.01 & $0.0241 * *$ & 0.01 & $0.0311 * *$ & 0.01 & $0.0189 * *$ & 0.009 \\
\hline ay1981 & $-0.1081 * * *$ & 0.03 & $-0.0491 *$ & 0.03 & 0.0039 & 0.03 & 0.0047 & 0.04 & -0.0205 & 0.023 \\
\hline ay1982 & $-0.1760 * * *$ & 0.03 & $-0.1553 * * *$ & 0.03 & $-0.1666 * * *$ & 0.03 & $-0.1772 * * *$ & 0.04 & $-0.1425 * * *$ & 0.024 \\
\hline ay1983 & $-0.1023 * * *$ & 0.03 & $-0.0460 *$ & 0.03 & $-0.0525 *$ & 0.03 & -0.0148 & 0.04 & -0.0272 & 0.024 \\
\hline ay1984 & $-0.0751 * *$ & 0.03 & 0.0027 & 0.02 & $0.0624 * *$ & 0.03 & $0.0735 * *$ & 0.03 & $0.0408 *$ & 0.022 \\
\hline ay1985 & $0.1190 * * *$ & 0.03 & $0.1869 * * *$ & 0.02 & $0.2256 * * *$ & 0.03 & $0.2268 * * *$ & 0.03 & $0.2260 * * *$ & 0.022 \\
\hline ay1986 & $0.3727 * * *$ & 0.03 & $0.4713 * * *$ & 0.02 & $0.5334 * * *$ & 0.03 & $0.4973 * * *$ & 0.03 & $0.4993 * * *$ & 0.022 \\
\hline ay1987 & $0.8019 * * *$ & 0.03 & $0.8973 * * *$ & 0.02 & $0.9896 * * *$ & 0.03 & $0.9913 * * *$ & 0.03 & $0.9578 * * *$ & 0.021 \\
\hline ay 1988 & $1.0988 * * *$ & 0.03 & $1.1907 * * *$ & 0.02 & $1.2583 * * *$ & 0.03 & $1.2777 * * *$ & 0.03 & $1.2398 * * *$ & 0.021 \\
\hline ay1989 & $1.4918 * * *$ & 0.03 & $1.6027 * * *$ & 0.02 & $1.7053 * * *$ & 0.03 & $1.6928 * * *$ & 0.03 & $1.6622 * * *$ & 0.021 \\
\hline ay 1990 & $1.5839 * * *$ & 0.03 & $1.7113 * * *$ & 0.02 & $1.8702 * * *$ & 0.03 & $1.9168 * * *$ & 0.03 & $1.7943 * * *$ & 0.021 \\
\hline ay1991 & $1.2495 * * *$ & 0.03 & $1.2712 * * *$ & 0.03 & $1.3181 * * *$ & 0.03 & $1.2944 * * *$ & 0.04 & $1.2958 * * *$ & 0.024 \\
\hline ay1992 & $1.1472 * * *$ & 0.03 & $1.2140 * * *$ & 0.03 & $1.2064 * * *$ & 0.03 & $1.2129 * * *$ & 0.04 & $1.2144 * * *$ & 0.023 \\
\hline ay 1993 & $0.9927 * * *$ & 0.03 & $1.0222 * * *$ & 0.02 & $1.0536 * * *$ & 0.03 & $1.0436 * * *$ & 0.03 & $1.0539 * * *$ & 0.023 \\
\hline ay1994 & $0.9632 * * *$ & 0.03 & $1.0050 * * *$ & 0.02 & $1.0362 * * *$ & 0.03 & $1.0443 * * *$ & 0.03 & $1.0275 * * *$ & 0.022 \\
\hline ay1995 & $1.0394 * * *$ & 0.03 & $1.0859 * * *$ & 0.03 & $1.0998 * * *$ & 0.03 & $1.0789 * * *$ & 0.04 & $1.1150 * * *$ & 0.023 \\
\hline ay 1996 & $1.0064 * * *$ & 0.03 & $1.0550 * * *$ & 0.02 & $1.0804 * * *$ & 0.03 & $1.0974 * * *$ & 0.03 & $1.0981 * * *$ & 0.022 \\
\hline ay1997 & $1.0273 * * *$ & 0.03 & $1.0738 * * *$ & 0.02 & $1.0923 * * *$ & 0.03 & $1.0894 * * *$ & 0.03 & $1.1231 * * *$ & 0.023 \\
\hline ay 1998 & $1.0813 * * *$ & 0.03 & $1.1616 * * *$ & 0.03 & $1.2022 * * *$ & 0.03 & $1.1890 * * *$ & 0.04 & $1.2274 * * *$ & 0.023 \\
\hline ay1999 & $1.1644 * * *$ & 0.03 & $1.2178 * * *$ & 0.03 & $1.2400 * * *$ & 0.03 & $1.2164 * * *$ & 0.04 & $1.2783 * * *$ & 0.024 \\
\hline ay 2000 & $1.1396 * * *$ & 0.03 & $1.2227 * * *$ & 0.03 & $1.2741 * * *$ & 0.03 & $1.2599 * * *$ & 0.04 & $1.3127 * * *$ & 0.024 \\
\hline ay2001 & $1.0921 * * *$ & 0.03 & $1.1741 * * *$ & 0.03 & $1.2559 * * *$ & 0.03 & $1.2584 * * *$ & 0.04 & $1.2812 * * *$ & 0.024 \\
\hline ay 2002 & $1.1820 * * *$ & 0.04 & $1.2789 * * *$ & 0.03 & $1.3491 * * *$ & 0.03 & $1.3448 * * *$ & 0.04 & $1.3727 * * *$ & 0.025 \\
\hline ay2003 & $1.3049 * * *$ & 0.04 & $1.4077 * * *$ & 0.03 & $1.4929 * * *$ & 0.03 & $1.4587 * * *$ & 0.04 & $1.4855 * * *$ & 0.025 \\
\hline ay2004 & $1.4764 * * *$ & 0.04 & $1.5895 * * *$ & 0.03 & $1.7017 * * *$ & 0.03 & $1.7007 * * *$ & 0.04 & $1.7005 * * *$ & 0.025 \\
\hline ay2005 & $1.6346 * * *$ & 0.04 & $1.7423 * * *$ & 0.03 & $1.8719 * * *$ & 0.03 & $1.8296 * * *$ & 0.04 & $1.8586 * * *$ & 0.028 \\
\hline
\end{tabular}




\begin{tabular}{|c|c|c|c|c|c|c|c|c|c|c|}
\hline LNPRICE & Coeff. & SE & Coeff. & SE & Coeff. & SE & Coeff. & SE & Coeff. & SE \\
\hline $\operatorname{cdec} 1870$ & $-1.2871 * * *$ & 0.18 & $-1.0974 * * *$ & 0.14 & -0.0529 & 0.16 & 0.2351 & 0.20 & $-0.3382 * * *$ & 0.132 \\
\hline cdec 1880 & 0.0871 & 0.09 & $0.1206^{*}$ & 0.07 & $0.9880 * * *$ & 0.07 & $1.3907 * * *$ & 0.09 & $0.6599 * * *$ & 0.061 \\
\hline $\operatorname{cdec} 1890$ & 0.0912 & 0.08 & $0.1458 * *$ & 0.06 & $0.8808 * * *$ & 0.07 & $0.9794 * * *$ & 0.08 & $0.5921 * * *$ & 0.054 \\
\hline cdec 1900 & $0.1873 * *$ & 0.08 & $0.2057 * * *$ & 0.06 & $0.9037 * * *$ & 0.06 & $1.1520 * * *$ & 0.08 & $0.6569 * * *$ & 0.051 \\
\hline $\operatorname{cdec} 1910$ & $0.2037 * * *$ & 0.07 & $0.2327 * * *$ & 0.06 & $0.8374 * * *$ & 0.06 & $1.0004 * * *$ & 0.07 & $0.6067 * * *$ & 0.050 \\
\hline cdec 1920 & $0.1587^{* *}$ & 0.07 & $0.1721 * * *$ & 0.06 & $0.6766 * * *$ & 0.06 & $0.7561 * * *$ & 0.07 & $0.4841 * * *$ & 0.050 \\
\hline cdec 1930 & $0.1815^{* *}$ & 0.07 & $0.1479 * * *$ & 0.06 & $0.5721 * * *$ & 0.06 & $0.6301 * * *$ & 0.07 & $0.4190 * * *$ & 0.050 \\
\hline cdec 1940 & $0.1733^{* *}$ & 0.07 & $0.1252^{* *}$ & 0.06 & $0.5186^{* * *}$ & 0.06 & $0.5349 * * *$ & 0.07 & $0.3835 * * *$ & 0.050 \\
\hline cdec 1950 & 0.0814 & 0.07 & 0.0123 & 0.06 & $0.3388^{* * *}$ & 0.06 & $0.3085 * * *$ & 0.07 & $0.2261 * * *$ & 0.049 \\
\hline cdec 1960 & -0.0189 & 0.07 & $-0.1206^{* *}$ & 0.06 & $0.1430^{*}$ & 0.06 & 0.0821 & 0.07 & 0.0638 & 0.049 \\
\hline cdec 1970 & $-0.1400 * *$ & 0.07 & $-0.2846^{* * *}$ & 0.06 & -0.0872 & 0.06 & $-0.1651^{* *}$ & 0.07 & $-0.1549 * * *$ & 0.049 \\
\hline $\operatorname{cdec} 1980$ & $-0.1540 * *$ & 0.07 & $-0.3117^{* * *}$ & 0.06 & $-0.1769^{* * *}$ & 0.06 & $-0.2931 * * *$ & 0.07 & $-0.2316^{* * *}$ & 0.049 \\
\hline cdec 1990 & $-0.1645 * *$ & 0.07 & $-0.3418^{* * *}$ & 0.06 & $-0.1472 * *$ & 0.06 & $-0.2363 * * *$ & 0.07 & $-0.2204 * * *$ & 0.050 \\
\hline TSD & $-0.0149^{* *}$ & 0.00 & $-0.0148^{* * *}$ & 0.00 & $-0.0129 * * *$ & 0.00 & $-0.0093 * * *$ & 0.00 & $-0.0138^{* * *}$ & 0.001 \\
\hline D-Dage & $-0.0438^{* * *}$ & 0.01 & $-0.0478^{* * *}$ & 0.01 & $-0.0618^{* * *}$ & 0.01 & $-0.0625^{* * *}$ & 0.01 & $-0.0526^{* * *}$ & 0.005 \\
\hline D-Dage2 & $1.0857 * * *$ & 0.18 & $1.1687^{* * *}$ & 0.15 & $1.4773^{* * *}$ & 0.17 & $1.5087 * * *$ & 0.20 & $1.2807^{* * *}$ & 0.136 \\
\hline D-Dage 3 & $-0.0066^{* * *}$ & 0.00 & $-0.0070^{* * *}$ & 0.00 & $-0.0086^{* * *}$ & 0.00 & $-0.0088 * * *$ & 0.00 & $-0.0076^{* * *}$ & 0.001 \\
\hline Constant & $6.4448 * * *$ & 0.13 & $6.4264 * * *$ & 0.10 & $6.4909^{* * *}$ & 0.11 & $6.6770 * * *$ & 0.13 & $5.5609 * * *$ & 0.054 \\
\hline Observations & 146,575 & & 146,575 & & 146,575 & & 146,575 & & 146,575 & \\
\hline Pseudo $\mathrm{R}^{2}$ & 0.4396 & & 0.4677 & & 0.5246 & & 0.5429 & & 0.7298 & \\
\hline
\end{tabular}

Table 3 shows the estimation results of the $10 \%, 25 \%, 75 \%$, and $90 \%$ quantile regressions, as well as the OLS estimates for comparison. The results with respect to the death effect confirm our OLS estimates. For all four quantiles we obtain an inverted U-shaped relationship between the death effect and the age at death, the critical age at which the effects becomes positive occurring at an age of 71 or 72. Figure 7 depicts the respective plots.

Figure 7: Death effect profiles for different quantiles

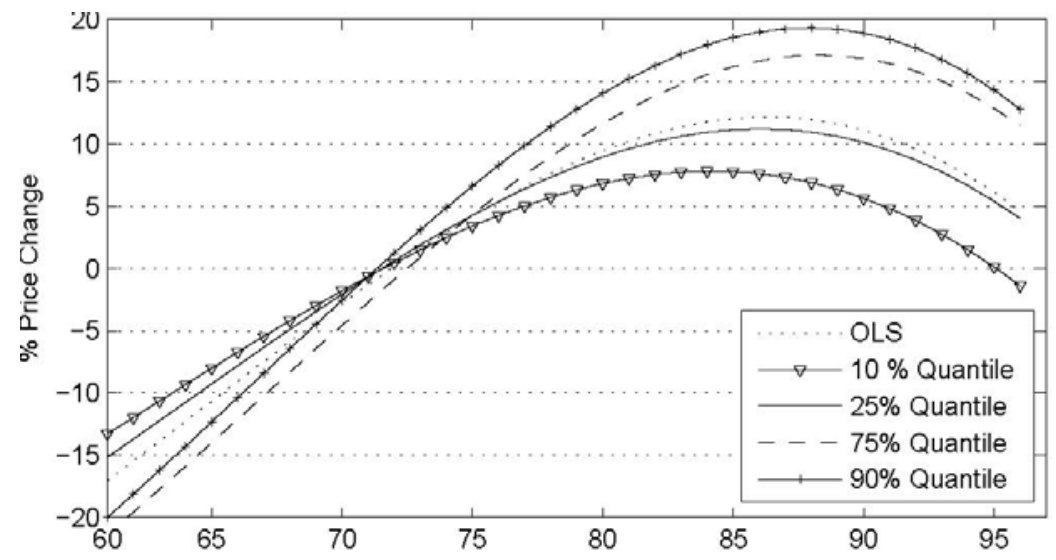

The plots shown in Figure 7 indicate that the death effect is more pronounced in the upper tail of the distribution (75\% and $90 \%$ quantile) as compared to the OLS estimates, and smaller for lower 
quantiles $(10 \%$ and $25 \%) .{ }^{10}$ At an age at death of, for example, 65 years, the death-induced price decrease amounts to $14 \%(12 \%)$ in the $75 \%(90 \%)$ quantile, but only $7 \%(8 \%)$ in the $10 \%(25 \%)$ quantile. This corresponds well to our fourth hypothesis. Collectors buy works of potential future leading artist and thereby create upward pressure on the prices. If, however, the artist dies an untimely death, the hopes of the collectors are dashed and the prices drop. This effect is larger for great talents because the relationship between reputation and commercial success is highly non-linear. ${ }^{11}$ For higher ages at death, the line-up of the death-induced price increases corresponds even better to the theoretical predictions: at an age at death of, for example, 85 years, the estimated death effects amount to $7 \%, 11 \%, 16 \%$ and $18 \%$ for the $10 \%, 25 \%, 75 \%$, and $90 \%$ quantile. In interpreting these results, it is important to remember that we are dealing here with a sample of top achievers since we excluded all artists with less than 250 observations. We conjecture that the death effect would be significantly smaller for the excluded (less well-known) artists than the death effects identified here for the artists making up the bottom $10 \%$ of our sample of renowned artists.

With respect to the remaining explanatory variables, the quantile regressions yield some qualifications of the OLS estimates. First, the mark-up for oil paintings is especially pronounced for highly priced works of art. The coefficient is roughly twice as large for the $90 \%$ quantile than for the $10 \%$ quantile. The same holds for works on paper. Second, a signature is more important for less valuable artwork, price differences amounting to $25 \%$ for the $10 \%$ quantile and only $11 \%$ for the $90 \%$ quantile. We conjecture that for expensive artwork authentication is possible even if a piece is not signed, while for cheaper artwork the signature is the only (financially viable) authentication device. This argument would also explain why Czujack (1997) did not find a significant signature-effect for Picasso's works of art which are, as a rule, very expensive. Third, the size-effect on prices for oil paintings and drawings on paper does not appear to depend on quality, for prints, however, it does. Our estimates indicate that the size-induced price differences of prints vary positively with artistic achievement. A $10 \mathrm{~cm}$ increase in the height of a print yields a $38 \%$ price increase for prints created by artists in the $10 \%$ quantile, while the corresponding increase amounts to $96 \%$ for prints by artists in the $90 \%$ quantile. The same holds for the width of a print. Fourth, the skyrocketing prices for late $19^{\text {th }}$ century and early $20^{\text {th }}$ century art are driven by high-end sales. The ratio between the estimated coefficients for these periods and those for the second half of the $20^{\text {th }}$ century are much higher for the $75 \%$ and $90 \%$ quantiles than for the $10 \%$ and $25 \%$ quantiles. Finally, prices of artwork created by deceased minor artists depreciate much faster than the prices of artwork created by major artists, indicating that changes in preferences and taste cannot do much harm to artwork that is considered to be a topachievement of a period even if the respective style does not anymore agree with current tastes.

\footnotetext{
${ }^{10}$ We do not report the estimates for the median quantile, because they do not differ significantly from the OLS estimates.

${ }^{11}$ The classic study on superstars is Rosen (1981).
} 


\section{Conclusions}

In this study we extended the theory explaining death-induced changes in art prices by acknowledging that demand for works of art is to a large extent driven by the respective artist's reputation. We furthermore conduct a theory guided empirical test which takes into account that the direction and the size of the death effect depend on the artist's age at death. Our main theoretical contribution consists in demonstrating that the death effect is negative in the case of an untimely death. This result complements previous theoretical considerations that have focused on death-induced price increases. The negative death effect materializes because it takes a long time to build up a sustainable reputation in the global arts market. Thus, if a promising artist dies before her reputation reaches the level commensurate with the artistic quality of her work, the early collectors' hopes of owning a piece of art that is generally recognized to represent the value that would actually be justified by the artistic quality, is frustrated. The prices thus decrease after the artist's death.

Our empirical investigation shows that the death effect is indeed negative for artists who are unlucky enough to die young. It also shows that the reputation effect diminishes with increasing age at death, with the consequence that the traditional positive scarcity effect governs the price changes observed after the death of artists who die at a ripe age after having gained the reputation which they deserve. Our empirical results, moreover, bear out the prediction that the work of top artists is subject to more pronounced death effects than the work of merely accomplished artists, and the work of journeymen artists is even less affected.

We derive our empirical results from a data set comprising more than 400,000 observations. Since our analysis of the death effect is embedded in a set of standard hedonic art price regressions, we are able to reconfirm many results previously derived from much smaller datasets. In particular, we use our large dataset to run quantile regressions which reveal that the influence of some price determinants varies substantially across price or quality ranges. All our results are robust with respect to various econometric specifications and estimation techniques.

Our investigation has documented that reputation is a crucial determinant of art prices. Even though this is hardly a novel insight, it is worth emphasizing that the mechanisms underlying the death effect cannot be properly understood without taking the accumulation of reputation into account. The empirical literature has a tendency to downplay the influence of reputation because it is hard to measure. Future empirical research into art price formation, in general, and the death effect, in particular, would enormously benefit from a reputation measure which is independent of art prices or the length of the artists' careers. ${ }^{12}$

\footnotetext{
${ }^{12}$ The "citation method", i.e. counting the number of reproductions or the length of entries in art history textbooks, represents a promising starting point. It can, however, only be applied to a relatively small number of artists with a claim to superstar status.
} 


\section{References}

Agnello; R.J. (2002): Investment returns and risk for art: Evidence from auctions of American paintings, Eastern Economic Journal 28, 443-463.

Beckert, J. and J. Rössel (2004): Reputation as a mechanism for reducing uncertainty in the art market (in German), Kölner Zeitschrift für Soziologie und Sozialpsychologie 56(1), 32-50.

Ashenfelter, O., and K. Graddy (2006): Art auctions, in the Handbook of the Economics of Art and Culture, Volume 1, V.A. Ginsburgh and D. Throsby (eds.), Elsevier.

Coase, R. (1972): Durability and monopoly, Journal of Law and Economics 15(1), 143-149.

Czujack, C. (1997): Picasso painting at auction, 1963-1994, Journal of Cultural Economics 21(3), 229-247.

Edwards, S. (2004): The economics of Latin American art: Creativity patterns and rates of return, Economia: Journal of the Latin American and Caribbean Economic Association 4(2), 1-35.

Ekelund, R. B., R. W. Ressler, and J. K. Watson (2000): The "Death-Effect" in art prices: A demand side exploration, Journal of Cultural Economics 24(4), 283-300.

Frey, B.S. and R. Eichenberger (1995): On the rate of return in the art market: Survey and evaluation, European Economic Review 39(3-4), 528-537.

Galenson, D.W. and B.A Weinberg (2001): Creating moden art: The changing careers of painters in France from Impressionism to Cubism, American Economic Review 91(4), 1063-1071.

Galenson, D. W., and B. A. Weinberg (2000): “Age and the Quality of Work: The Case of modern American painters," Journal of Political Economy 108(4), 761-777.

Ginsburgh, V., J. Mei and M. Moses (2006): The computation of prices indices, in the Handbook of the Economics of Art and Culture, Volume 1, V.A. Ginsburgh and D. Throsby (eds.), Elsevier.

Ginsburgh, V. and S. Weyers (2006): Creativity and life cycles of artists, Journal of Cultural Economics 30, 91-107.

Itaya, J.-I., and H. W. Ursprung (2008): Price and death, forthcoming, mimeo, Hokkaido University.

Koenker, R., and G. Bassett (1978): Regression quantiles, Econometrica, 46(1), 33-50.

Koenker, R., and K. F. Hallock (2001): Quantile Regressions, Journal of Economic Perspectives 15(4), 143-156.

Maddison, D and A. Jul-Pedersen (2007): The death effect in art prices: Evidence from Denmark, forthcoming in Applied Economics.

Mei, J., and M. Moses (2002): Art as an investment and the underperformance of masterpieces," American Economic Review 92(5), 1656-1668.

Pesando, J. E. (1993): Art as an investment. The market for modern prints, American Economic Review 83(5), 1075-1089.

Pesando, J. E., and P. Shum (1996): Price anomalies at auction: Evidence from the market for modern prints," in Economics of the Arts: Selected numbers, ed. by V. Ginsburgh, and P.-M. Menger. Elsevier, Amsterdam.

Rosen, S. (1981): The economics of superstars, American Economic Review 71(5), 845-858.

Worthington, A.C. and H. Higgs (2006): A note on financial risk, return and asset pricing in Australian modern and contemporary art, Journal of Cultural Economics 30, 73-84. 


\section{Appendix 1: Data Description}

Oil: 1 if artwork is an oil painting

Paper: 1 if artwork is on paper

Print: 1 if artwork is a print

Dage: Age at death, i.e. death year - birth year if artist is dead, 0 if artist is alive

Death: 1 if auction year equals death year, death year +1 or death year +2

D-Dage (Death times Dage),

D-DageS (D-Dage squared), D-DageT (D-Dage to the power of three), D-DageQ (D-Dage to the power of four) and D-DageP (D-Dage to the power of five), all divided by 1000

TSD: Time since death, i.e. auction year - death year, if auction year $>$ death year +2

Signature: 1 if the work of art is signed by the artist

Ln Price: Logarithm of the real price in US-\$, using the US-All-Urban CPI (1982=100)

Supply: Number of works of art (by the respective artist) auctioned in the respective year

Width: Width of the work of art in metres

Height: Height of the work of art in metres

OilWidth (Oil times Width), OilHeight (Oil times Height), OilsWidthS (OilWidth squared),Oil-

HeightS (OilHeight squared), PaperWidth, PaperHeight, PaperWidthS, PaperHeightS,

PrintWidth, PrintHeight ared defined corrspondingly

CHLO (SOLO): 1 if sold at Christie's (Sotheby's) London

CHNY (SONY): 1 if sold at Christie's (Sotheby's) New York

CHPA (SOPA): 1 if sold at Christie's (Sotheby's) Paris

CHUS (SOUS): 1 if sold at Christie's (Sotheby's) in the US, but not in New York

CHEU (SOEU): 1 if sold at Christie's (Sotheby's) in Europe, but not in Paris or London

NY: 1 if sold in New York, excluding Sotheby's and Christie's

LO: 1 if sold in London, excluding Sotheby's and Christie's

PA: 1 if sold in Paris, excluding Sotheby's and Christie's

US: 1 if sold in the US, but not at Sotheby's or Christie's and not in New York

EU: 1 if sold in the Europe, but not at Sotheby's or Christie's and not in London or Paris

JAP: 1 if sold in Japan

ay 1980: 1 if auction year is 1980, etc.

cdec1870: 1 if creation year is between 1870 and 1880, etc.

cdec2000: 1 if creation year is between 2000 and 2005 


\section{Appendix 2: Summary Statistics}

The following table reports the summary statistics of our data sets. The reduced sample excludes all artists with less than 250 auction records. The full dataset consists of 436,308 observations, the reduced sample of 146,575 .

\begin{tabular}{|c|c|c|c|c|c|c|c|c|}
\hline & \multicolumn{4}{|c|}{ Full Sample } & \multicolumn{4}{|c|}{ Reduced Sample } \\
\hline Variable & Mean & Std. Dev. & Min & Max & Mean & Std. Dev. & Min & Max \\
\hline Oil & 0.589 & 0.492 & 0 & 1 & 0.414 & 0.493 & 0 & 1 \\
\hline Paper & 0.351 & 0.477 & 0 & 1 & 0.443 & 0.497 & 0 & 1 \\
\hline Print & 0.060 & 0.237 & 0 & 1 & 0.143 & 0.350 & 0 & 1 \\
\hline Auctionyear & 1996 & 6.647 & 1980 & 2005 & 1995 & 6.850 & 1980 & 2005 \\
\hline Birthyear & 1903 & 25.086 & 1820 & 1980 & 1899 & 22.395 & 1858 & 1961 \\
\hline Deathyear & 1968 & 20.553 & 1900 & 2005 & 1971 & 18.192 & 1920 & 2004 \\
\hline Dage & 75.263 & 13.134 & 18 & 112 & 77.785 & 12.089 & 28 & 98 \\
\hline Death & 0.032 & 0.177 & 0 & 1 & 0.035 & 0.183 & 0 & 1 \\
\hline TSD & 21.019 & 21.298 & 0 & 105 & 20.999 & 18.874 & 0 & 85 \\
\hline Signature & 0.881 & 0.323 & 0 & 1 & 0.877 & 0.328 & 0 & 1 \\
\hline LnPrice & 8.420 & 1.559 & 5.263 & 18.348 & 9.217 & 1.619 & 5.613 & 18.348 \\
\hline Supply & 28.042 & 81.990 & 1 & 831 & 71.275 & 130.638 & 1 & 831 \\
\hline Width & 0.628 & 0.424 & 0.01 & 12.7 & 0.570 & 0.405 & 0.01 & 11.13 \\
\hline Height & 0.607 & 0.396 & 0.01 & 10.16 & 0.554 & 0.369 & 0.02 & 9.01 \\
\hline OilWidth & 0.430 & 0.495 & 0 & 11.13 & 0.295 & 0.459 & 0 & 11.13 \\
\hline OilHeight & 0.410 & 0.467 & 0 & 9.22 & 0.282 & 0.427 & 0 & 7.75 \\
\hline OilWidthS & 0.430 & 1.184 & 0 & 123.877 & 0.298 & 1.151 & 0 & 123.877 \\
\hline OilHeightS & 0.387 & 0.842 & 0 & 85.008 & 0.262 & 0.688 & 0 & 60.062 \\
\hline PaperWidth & 0.165 & 0.298 & 0 & 12.7 & 0.196 & 0.296 & 0 & 6.1 \\
\hline PaperHeight & 0.162 & 0.288 & 0 & 10.16 & 0.191 & 0.282 & 0 & 9.01 \\
\hline PaperWidthS & 0.116 & 0.593 & 0 & 161.29 & 0.126 & 0.497 & 0 & 37.21 \\
\hline PaperHeightS & 0.109 & 0.481 & 0 & 103.2256 & 0.116 & 0.435 & 0 & 81.18011 \\
\hline PrintWidth & 0.033 & 0.167 & 0 & 9.75 & 0.078 & 0.244 & 0 & 9.75 \\
\hline PrintHeight & 0.034 & 0.166 & 0 & 6.43 & 0.081 & 0.243 & 0 & 6.43 \\
\hline SOLO & 0.059 & 0.236 & 0 & 1 & 0.094 & 0.293 & 0 & 1 \\
\hline SONY & 0.072 & 0.258 & 0 & 1 & 0.107 & 0.309 & 0 & 1 \\
\hline SOPA & 0.001 & 0.023 & 0 & 1 & 0.001 & 0.026 & 0 & 1 \\
\hline SOUS & 0.006 & 0.080 & 0 & 1 & 0.005 & 0.070 & 0 & 1 \\
\hline SOEU & 0.031 & 0.173 & 0 & 1 & 0.025 & 0.158 & 0 & 1 \\
\hline CHLO & 0.048 & 0.213 & 0 & 1 & 0.076 & 0.265 & 0 & 1 \\
\hline CHNY & 0.042 & 0.200 & 0 & 1 & 0.062 & 0.241 & 0 & 1 \\
\hline CHPA & 0.001 & 0.030 & 0 & 1 & 0.001 & 0.033 & 0 & 1 \\
\hline CHUS & 0.053 & 0.223 & 0 & 1 & 0.039 & 0.194 & 0 & 1 \\
\hline CHEU & 0.031 & 0.173 & 0 & 1 & 0.049 & 0.216 & 0 & 1 \\
\hline NY & 0.018 & 0.132 & 0 & 1 & 0.018 & 0.132 & 0 & 1 \\
\hline LO & 0.016 & 0.124 & 0 & 1 & 0.011 & 0.106 & 0 & 1 \\
\hline PA & 0.118 & 0.323 & 0 & 1 & 0.140 & 0.347 & 0 & 1 \\
\hline US & 0.040 & 0.196 & 0 & 1 & 0.015 & 0.120 & 0 & 1 \\
\hline EU & 0.466 & 0.499 & 0 & 1 & 0.357 & 0.479 & 0 & 1 \\
\hline JAP & 0.000 & 0.011 & 0 & 1 & 0.000 & 0.019 & 0 & 1 \\
\hline
\end{tabular}




\begin{tabular}{|c|c|c|c|c|c|c|c|c|}
\hline Variable & Mean & Std. Dev. & Min & Max & Mean & Std. Dev. & Min & Max \\
\hline ay1980 & 0.014 & 0.118 & 0 & 1 & 0.018 & 0.133 & 0 & 1 \\
\hline ay1981 & 0.014 & 0.119 & 0 & 1 & 0.018 & 0.132 & 0 & 1 \\
\hline ay1982 & 0.012 & 0.109 & 0 & 1 & 0.015 & 0.121 & 0 & 1 \\
\hline ay1983 & 0.014 & 0.118 & 0 & 1 & 0.017 & 0.129 & 0 & 1 \\
\hline ay1984 & 0.018 & 0.133 & 0 & 1 & 0.022 & 0.146 & 0 & 1 \\
\hline ay1985 & 0.020 & 0.141 & 0 & 1 & 0.024 & 0.153 & 0 & 1 \\
\hline ay1986 & 0.021 & 0.143 & 0 & 1 & 0.024 & 0.152 & 0 & 1 \\
\hline ay1987 & 0.027 & 0.163 & 0 & 1 & 0.031 & 0.174 & 0 & 1 \\
\hline ay1988 & 0.030 & 0.171 & 0 & 1 & 0.033 & 0.178 & 0 & 1 \\
\hline ay1989 & 0.040 & 0.196 & 0 & 1 & 0.044 & 0.205 & 0 & 1 \\
\hline ay1990 & 0.039 & 0.194 & 0 & 1 & 0.040 & 0.197 & 0 & 1 \\
\hline ay1991 & 0.025 & 0.157 & 0 & 1 & 0.023 & 0.148 & 0 & 1 \\
\hline ay1992 & 0.028 & 0.164 & 0 & 1 & 0.025 & 0.155 & 0 & 1 \\
\hline ay1993 & 0.035 & 0.185 & 0 & 1 & 0.033 & 0.178 & 0 & 1 \\
\hline ay1994 & 0.041 & 0.199 & 0 & 1 & 0.038 & 0.192 & 0 & 1 \\
\hline ay1995 & 0.042 & 0.200 & 0 & 1 & 0.038 & 0.191 & 0 & 1 \\
\hline ay1996 & 0.048 & 0.214 & 0 & 1 & 0.049 & 0.216 & 0 & 1 \\
\hline ay1997 & 0.054 & 0.227 & 0 & 1 & 0.059 & 0.235 & 0 & 1 \\
\hline ay1998 & 0.057 & 0.232 & 0 & 1 & 0.060 & 0.238 & 0 & 1 \\
\hline ay1999 & 0.056 & 0.229 & 0 & 1 & 0.055 & 0.228 & 0 & 1 \\
\hline ay2000 & 0.062 & 0.241 & 0 & 1 & 0.060 & 0.237 & 0 & 1 \\
\hline ay2001 & 0.063 & 0.243 & 0 & 1 & 0.058 & 0.233 & 0 & 1 \\
\hline ay2002 & 0.062 & 0.241 & 0 & 1 & 0.058 & 0.234 & 0 & 1 \\
\hline ay2003 & 0.066 & 0.248 & 0 & 1 & 0.063 & 0.242 & 0 & 1 \\
\hline ay2004 & 0.081 & 0.274 & 0 & 1 & 0.070 & 0.256 & 0 & 1 \\
\hline ay2005 & 0.030 & 0.170 & 0 & 1 & 0.027 & 0.162 & 0 & 1 \\
\hline cdec 1870 & 0.000 & 0.020 & 0 & 1 & 0.000 & 0.018 & 0 & 1 \\
\hline cdec 1880 & 0.006 & 0.079 & 0 & 1 & 0.005 & 0.070 & 0 & 1 \\
\hline cdec 1890 & 0.018 & 0.131 & 0 & 1 & 0.013 & 0.112 & 0 & 1 \\
\hline cdec 1900 & 0.040 & 0.195 & 0 & 1 & 0.035 & 0.184 & 0 & 1 \\
\hline cdec 1910 & 0.082 & 0.274 & 0 & 1 & 0.072 & 0.258 & 0 & 1 \\
\hline cdec 1920 & 0.111 & 0.314 & 0 & 1 & 0.106 & 0.308 & 0 & 1 \\
\hline cdec 1930 & 0.099 & 0.299 & 0 & 1 & 0.099 & 0.299 & 0 & 1 \\
\hline cdec 1940 & 0.106 & 0.308 & 0 & 1 & 0.116 & 0.320 & 0 & 1 \\
\hline cdec 1950 & 0.136 & 0.343 & 0 & 1 & 0.161 & 0.367 & 0 & 1 \\
\hline cdec1960 & 0.153 & 0.360 & 0 & 1 & 0.175 & 0.380 & 0 & 1 \\
\hline cdec 1970 & 0.106 & 0.308 & 0 & 1 & 0.112 & 0.315 & 0 & 1 \\
\hline cdec 1980 & 0.096 & 0.295 & 0 & 1 & 0.085 & 0.279 & 0 & 1 \\
\hline cdec 1990 & 0.039 & 0.194 & 0 & 1 & 0.020 & 0.194 & 0 & 1 \\
\hline cdec 2000 & 0.007 & 0.085 & 0 & 1 & 0.002 & 0.086 & 0 & 1 \\
\hline
\end{tabular}




\section{CESifo Working Paper Series}

for full list see www.cesifo-group.org/wp

(address: Poschingerstr. 5, 81679 Munich, Germany, office@cesifo.de)

2172 Patricia Apps and Ray Rees, Household Models: An Historical Perspective, December 2007

2173 Ben Greiner, Axel Ockenfels and Peter Werner, The Dynamic Interplay of Inequality and Trust - An Experimental Study, December 2007

2174 Michael Melvin and Magali Valero, The Dark Side of International Cross-Listing: Effects on Rival Firms at Home, December 2007

2175 Gebhard Flaig and Horst Rottmann, Labour Market Institutions and the Employment Intensity of Output Growth. An International Comparison, December 2007

2176 Alexander Chudik and M. Hashem Pesaran, Infinite Dimensional VARs and Factor Models, December 2007

2177 Christoph Moser and Axel Dreher, Do Markets Care about Central Bank Governor Changes? Evidence from Emerging Markets, December 2007

2178 Alessandra Sgobbi and Carlo Carraro, A Stochastic Multiple Players Multi-Issues Bargaining Model for the Piave River Basin, December 2007

2179 Christa Hainz, Creditor Passivity: The Effects of Bank Competition and Institutions on the Strategic Use of Bankruptcy Filings, December 2007

2180 Emilia Del Bono, Andrea Weber and Rudolf Winter-Ebmer, Clash of Career and Family: Fertility Decisions after Job Displacement, January 2008

2181 Harald Badinger and Peter Egger, Intra- and Inter-Industry Productivity Spillovers in OECD Manufacturing: A Spatial Econometric Perspective, January 2008

2182 María del Carmen Boado-Penas, Salvador Valdés-Prieto and Carlos Vidal-Meliá, the Actuarial Balance Sheet for Pay-As-You-Go Finance: Solvency Indicators for Spain and Sweden, January 2008

2183 Assar Lindbeck, Economic-Social Interaction in China, January 2008

2184 Pierre Dubois, Bruno Jullien and Thierry Magnac, Formal and Informal Risk Sharing in LDCs: Theory and Empirical Evidence, January 2008

2185 Roel M. W. J. Beetsma, Ward E. Romp and Siert J. Vos, Intergenerational Risk Sharing, Pensions and Endogenous Labor Supply in General Equilibrium, January 2008

2186 Lans Bovenberg and Coen Teulings, Rhineland Exit?, January 2008 
2187 Wolfgang Leininger and Axel Ockenfels, The Penalty-Duel and Institutional Design: Is there a Neeskens-Effect?, January 2008

2188 Sándor Csengődi and Dieter M. Urban, Foreign Takeovers and Wage Dispersion in Hungary, January 2008

2189 Joerg Baten and Andreas Böhm, Trends of Children's Height and Parental Unemployment: A Large-Scale Anthropometric Study on Eastern Germany, 1994 2006, January 2008

2190 Chris van Klaveren, Bernard van Praag and Henriette Maassen van den Brink, A Public Good Version of the Collective Household Model: An Empirical Approach with an Application to British Household Data, January 2008

2191 Harry Garretsen and Jolanda Peeters, FDI and the Relevance of Spatial Linkages: Do third Country Effects Matter for Dutch FDI?, January 2008

2192 Jan Bouckaert, Hans Degryse and Theon van Dijk, Price Discrimination Bans on Dominant Firms, January 2008

2193 M. Hashem Pesaran, L. Vanessa Smith and Takashi Yamagata, Panel Unit Root Tests in the Presence of a Multifactor Error Structure, January 2008

2194 Tomer Blumkin, Bradley J. Ruffle and Yosef Ganun, Are Income and Consumption Taxes ever really Equivalent? Evidence from a Real-Effort Experiment with Real Goods, January 2008

2195 Mika Widgrén, The Impact of Council's Internal Decision-Making Rules on the Future EU, January 2008

2196 Antonis Adam, Margarita Katsimi and Thomas Moutos, Inequality and the Import Demand Function, January 2008

2197 Helmut Seitz, Democratic Participation and the Size of Regions: An Empirical Study Using Data on German Counties, January 2008

2198 Theresa Fahrenberger and Hans Gersbach, Minority Voting and Long-term Decisions, January 2008

2199 Chiara Dalle Nogare and Roberto Ricciuti, Term Limits: Do they really Affect Fiscal Policy Choices?, January 2008

2200 Andreas Bühn and Friedrich Schneider, MIMIC Models, Cointegration and Error Correction: An Application to the French Shadow Economy, January 2008

2201 Seppo Kari, Hanna Karikallio and Jukka Pirttilä, Anticipating Tax Change: Evidence from the Finnish Corporate Income Tax Reform of 2005, January 2008

2202 Walter Krämer and André Güttler, On Comparing the Accuracy of Default Predictions in the Rating Industry, January 2008 
2203 Syed M. Ahsan and Panagiotis Tsigaris, The Efficiency Loss of Capital Income Taxation under Imperfect Loss Offset Provisions, January 2008

2204 P. Mohnen, F. C. Palm, S. Schim van der Loeff and A. Tiwari, Financial Constraints and other Obstacles: Are they a Threat to Innovation Activity?, January 2008

2205 Sascha O. Becker and Mathias Hoffmann, Equity Fund Ownership and the CrossRegional Diversification of Household Risk, January 2008

2206 Pedro R. D. Bom and Jenny E. Ligthart, How Productive is Public Capital? A MetaAnalysis, January 2008

2207 Martin Werding, Ageing and Productivity Growth: Are there Macro-level Cohort Effects of Human Capital?, January 2008

2208 Frederick van der Ploeg and Steven Poelhekke, Globalization and the Rise of MegaCities in the Developing World, February 2008

2209 Sara Biancini, Regulating National Firms in a Common Market, February 2008

2210 Jin Cao and Gerhard Illing, Liquidity Shortages and Monetary Policy, February 2008

2211 Mathias Kifmann, The Design of Pension Pay Out Options when the Health Status during Retirement is Uncertain, February 2008

2212 Laszlo Goerke, Tax Overpayments, Tax Evasion, and Book-Tax Differences, February 2008

2213 Jun-ichi Itaya and Heinrich W. Ursprung, Price and Death, February 2008

2214 Valentina Bosetti, Carlo Carraro and Emanuele Massetti, Banking Permits: Economic Efficiency and Distributional Effects, February 2008

2215 Assar Lindbeck, Mårten Palme and Mats Persson, Social Interaction and Sickness Absence, February 2008

2216 Gary E. Bolton and Axel Ockenfels, The Limits of Trust in Economic Transactions Investigations of Perfect Reputation Systems, February 2008

2217 Hartmut Egger and Peter Egger, The Trade and Welfare Effects of Mergers in Space, February 2008

2218 Dorothee Crayen and Joerg Baten, Global Trends in Numeracy 1820-1949 and its Implications for Long-Run Growth, February 2008

2219 Stephane Dees, M. Hashem Pesaran, L. Vanessa Smith and Ron P. Smith, Identification of New Keynesian Phillips Curves from a Global Perspective, February 2008

2220 Jerome L. Stein, A Tale of Two Debt Crises: A Stochastic Optimal Control Analysis, February 2008 
2221 Michael Melvin, Lukas Menkhoff and Maik Schmeling, Automating Exchange Rate Target Zones: Intervention via an Electronic Limit Order Book, February 2008

2222 Raymond Riezman and Ping Wang, Preference Bias and Outsourcing to Market: A Steady-State Analysis, February 2008

2223 Lars-Erik Borge and Jørn Rattsø, Young and Old Competing for Public Welfare Services, February 2008

2224 Jose Apesteguia, Steffen Huck, Jörg Oechssler and Simon Weidenholzer, Imitation and the Evolution of Walrasian Behavior: Theoretically Fragile but Behaviorally Robust, February 2008

2225 Walter Krämer, Long Memory with Markov-Switching GARCH, February 2008

2226 António Afonso and Christophe Rault, What do we really Know about Fiscal Sustainability in the EU? A Panel Data Diagnostic, February 2008

2227 Sergey M. Kadochnikov and Igor M. Drapkin, Market Structure, Technological Gap and Vertical Linkage Effects from Foreign Direct Investment, February 2008

2228 Guglielmo Maria Caporale, Davide Ciferri and Alessandro Girardi, Fiscal Shocks and Real Exchange Rate Dynamics: Some Evidence for Latin America, February 2008

2229 Scott Alan Carson, Geography and Insolation in $19^{\text {th }}$ Century US African-American and White Statures, February 2008

2230 Wolfgang Buchholz and Jan Schumacher, Discounting and Welfare Analysis Over Time: Choosing the $\eta$, February 2008

2231 M. Hashem Pesaran, Christoph Schleicher and Paolo Zaffaroni, Model Averaging in Risk Management with an Application to Futures Markets, February 2008

2232 Wilhelm Kohler, Offshoring: Why Do Stories Differ?, February 2008

2233 Stefan Bach, Giacomo Corneo and Viktor Steiner, Effective Taxation of Top Incomes in Germany, 1992-2002, February 2008

2234 Robert S. Chirinko, o: The Long And Short Of It, February 2008

2235 Volker Grossmann and Holger Strulik, Should Continued Family Firms Face Lower Taxes than other Estates?, February 2008

2236 Guido Tabellini, The Scope of Cooperation: Values and Incentives, February 2008

2237 Heinrich W. Ursprung and Christian Wiermann, Reputation, Price, and Death: An Empirical Analysis of Art Price Formation, March 2008 